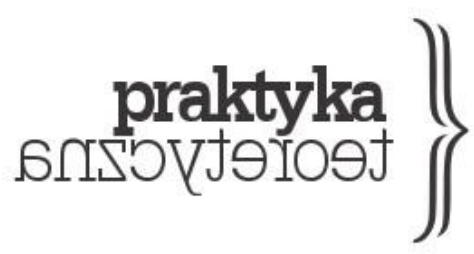

\title{
W STRONĘ EKONOMII POLITYCZNEJ „PRACY PUBLICZNOŚCI” W ERZE CYFROWEJ
}

\author{
BRICE NIXON
}

\begin{abstract}
Abstrakt: Artykuł rozwija teorię ekonomii politycznej skupiającej się na pojęciu „pracy publiczności”. Po pierwsze, krótko przedstawia wcześniej podejmowane próby wykorzystania tego pojęcia i proponuje ponowne przemyślenie pracy publiczności jako podstawy teorii ekonomii politycznej. Po drugie, rozwija teorię procesu pracy publiczności, korzystając zarówno z poprzednich teorii czynności publiczności w postaci konsumpcji kultury jako produktywnych czynności oznaczania (signification), jak również dopasowując marksowska koncepcję ludzkiego procesu pracy do procesu pracy publiczności. Po trzecie, naszkicowana zostaje ekonomia polityczna pracy publiczności. Jako teoria podstawowych procesów, przez które kapitał komunikacyjny może kontrolować i wyciagać wartość z pracy publiczności, opisuje ona wyzysk pracy publiczności i akumulację kapitału komunikacyjnego przez stosunki podziału oparte na rencie i procencie. Na koniec omówiona została stała i kluczowa rola wyzysku pracy publiczności w erze cyfrowej.
\end{abstract}

Słowa kluczowe: praca publiczności, kapitał komunikacyjny, produkcja komunikacyjna, konsumpcja kultury, wyzysk, renta 
Po niemal piętnastu latach formułowania teorii i analizowania różnych aspektów użycia mediów cyfrowych jako pracy cyfrowej ${ }^{1}$ wciąż brakuje rozważań nad specyfiką i znaczeniem pracy publiczności ${ }^{2}$. Podczas gdy narasta zainteresowanie ekonomia polityczna pracy cyfrowej, wciąż zdaje się brakować badań nad pracą publiczności jako szczególnym rodzajem pracy cyfrowej $^{3}$. Zrozumienie przez badaczy ekonomii politycznej komunikacji w erze cyfrowej jest utrudnione, ponieważ powszechnie ignoruje się specyfikę pracy publiczność. Choć Dallas Smythe, kanadyjski marksista i teoretyk mediów, prawie cztery dekady temu wprowadził do ekonomii politycznej komunikacji pojęcie „pracy publiczności”, to pomimo debat nad rzekomo „utowarowiona publicznościa” toczonych w latach siedemdziesiatych i osiemdziesiątych ubiegłego wieku nie zostało ono rozwinięte. Dopiero w XXI wieku kwestią pracy zainteresowała się znacznie większa liczba badaczy, posługujących się pojęciem pracy cyfrowej i innymi związanymi z nia pojęciami. Szczególny rodzaj pracy opisany przez Smythe'ego i innych jako praca publiczności jest nieobecny w tej dyskusji. W niniejszym artykule dowodzę jednak, że praca publiczności powinna stać się jednym z głównych pojęć ekonomii politycznej komunikacji. Postaram się pokazać produktywny potencjał tego zabiegu przez przedstawienie zarysu ekonomii politycznej pracy publiczności, ukazującej, jak tego rodzaju praca, przyjmująca postać konsumpcji kultury, jest wyzyskiwana (również w epoce cyfrowej, zakładającej, że „użytkownicy” i „prosumenci” zastąpili publiczność).

Uczynienie pracy publiczności głównym punktem przynajmniej części badań nad ekonomia polityczną komunikacji nie jest jednak prostym zadaniem. Pojęcie to nie może po prostu zostać zintegrowane z obecnym stanem badań nad pracą cyfrową ani wypreparowane z poprzednich badań. Zamiast tego koniecznym wydaje się powrót do pierwotnej konceptualizacji pracy publiczności, zapoczątkowanej przez Smythe'ego. W ten sposób możliwe będzie uzyskanie nowego punktu wyjścia, pozwalającego przekroczyć istniejące koncepcje i teorie pracy publiczności.

Wobec tego niezbędne wydaje się zmierzenie z szeregiem konceptualnych, teoretycznych i metodologicznych kwestii odnoszących się do komunikacji i ekonomii politycznej. Pojęcie pracy publiczności na wiele sposobów odsyła do sedna dawnych debat, toczonych między zwolennikami studiów kulturowych a przedstawicielami ekonomii

1 Tiziana Terranova (2000) zdaje się być pierwszą badaczką, która próbowała teoretyzować użycie mediów cyfrowych jako pracy, konkretnie jako formy „darmowej pracy”.

2 Dziękujemy redakcji czasopisma naukowego „tripleC: Communication, Capitalism \& Critique. Open Access Journal for a Global Sustainable Information Society" za zgodę na tłumaczenie niniejszego artykułu. W pierwotnej wersji ukazał się numerze „trpleC”, Vol. 12, No. 2 (2014), http://www.triplec.at/index.php/tripleC/article/view/535

3 Jedynym wyjątkiem jest Shawn Shimpach (2005), który dowodzi, że publiczność zawsze pracowała i robi to wciąż, używając mediów cyfrowych, mimo że jej czynności nie zostały rozpoznane jako rodzaj pracy. Shimpach nie podejmuje jednak próby konceptualizacji specyfiki pracy publiczności, co uważam za niezbędne dla zrozumienia, w jaki sposób praca ta jest przedmiotem kontroli i źródłem wartości dla rozlicznych przemysłów. 
politycznej, ponieważ z jednej strony czynności publiczności ewidentnie obejmują konsumpcję kultury i oznaczania, a z drugiej konceptualizacja tych czynności jako pracy publiczności pociaga za sobą włączenie ich w obręb ekonomii politycznej. Jakakolwiek próba włączenia czynności publiczności w tryby ekonomii politycznej powinna być jednak podejmowana z intencją ominięcia ślepych zaułków, w jakich utknęły poprzednie debaty (Peck 2006; Schiller 1996). Moim zdaniem rozpoczęcie od pojęcia pracy publiczności i rozwijanie teorii procesu pracy publiczności, powiązanego bezpośrednio z cyrkulacją oraz akumulacją kapitału, jest właśnie odpowiednim sposobem rozwiązania tego problemu. W następnej części artykułu postaram się podążać tą ścieżką aż do samych podstaw ekonomii politycznej pracy publiczności, stanowiących punkt wyjścia do zrozumienia trwałych podstaw wyzysku pracy publiczności w erze cyfrowej.

\section{Konceptualizowanie „pracy publiczności” w ramach „produkcji komunikacyjnej"}

Naszkicuję najpierw zarys historii pojęcia pracy publiczności. Utrzymuję, że jej początkowe konceptualizacje stanowią użyteczny punkt wyjścia dla prób rekonstrukcji ekonomii politycznej pracy publiczności, mimo że do tej pory zostały rozwinięte w stosunkowo małym stopniu. Ponadto dowodzę, że wiele bieżących koncepcji pracy cyfrowej ignoruje lub nie precyzuje cyfrowej pracy publiczności. Omawiam również metodę ekonomii politycznej komunikacji, która umożliwia teoretyczne rozważania nad czynnościami publiczności w postaci konsumpcji kultury rozumianymi jako praca, dzięki czemu kontrola kapitału nad nimi może być w jasny sposób postrzegana w kategoriach wyzysku. Następnie kontynuował będę starania Raymonda Williamsa mające na celu steoretyzowanie komunikacji jako procesu produkcji, w który włączona jest również praca publiczności.

\section{1. „Praca publiczności” w ekonomii politycznej komunikacji}

Aby rozwinać teorię ekonomii politycznej pracy publiczności w erze cyfrowej, praca publiczności musi zostać ponownie skonceptualizowana i oddzielona od mylnej koncepcji utowarowionej publiczności. Czynności będące swoistymi działaniami publiczności (czytanie, słuchanie i oglądanie), takie, które określić można też czynnościami konsumpcji w znaczeniu konsumpcji treści, muszą być rozumiane jako konstytuujące szczególny rodzaj pracy. Podążając za Smythe’em i innymi, nazwę je praca publiczności. Co więcej, te czynności konsumpcyjne powinny być jednocześnie traktowane jako czynności produkcji, co pozwala dostrzec, jak konstytuuja ten szczególny rodzaj pracy. Produktem będącym wynikiem czynności publiczności zajmę się w dalszych częściach. Tutaj natomiast pokrótce przedstawię konceptualizację pracy publiczności wewnątrz pola ekonomii politycznej komunikacji, 
począwszy od rozważań Smythe'ego z 1977 roku, aż po teoretyków pracy cyfrowej z XXI wieku. Dowodzę, że pojęcie pracy publiczności zostało stosunkowo słabo rozwinięte w dorobku tych nielicznych badaczy, którzy zajmowali się nim pod koniec ubiegłego stulecia. Uważam poza tym, że pojęcie to jest całkowicie nieobecne w ostatnich teoriach pracy cyfrowej. Czynności konsumpcji, które charakteryzują czynności wykonywane przez publiczność, są ignorowane (lub połączone z innymi czynnościami), podczas gdy uwaga badaczy skupia się na kulturalnej produkcji użytkowników mediów cyfrowych i na produkcji opartej na inwigilacji wytwórców i danych zebranych na ich temat.

Praca publiczności została wprowadzona po raz pierwszy jako pojęcie z zakresu ekonomii politycznej komunikacji w 1977 roku, gdy Smythe stwierdził, że w „analizach prowadzonych na gruncie zachodniego marksizmu” nie postawiono pytania o to, ,jaką ekonomiczną funkcję dla kapitału" spełniaja systemy masowej komunikacji; pytano w ich ramach natomiast wyłącznie o to, jaką ,ideologiczną" funkcję sprawują te systemy (Smythe 1977, 1). Smythe zbadał ich „ekonomiczna funkcje” i wywnioskował, że „przełomowym pytaniem” staje się pytanie o to, „co jest towarową formą masowo produkowanej i wspieranej przez reklamodawców komunikacji?” (1977, 2). Jego odpowiedź brzmiała: publiczność jako towar. Następnie postawił kolejny problem: Czym jest towar publiczności? W tym wypadku Smythe odpowiadał: siła robocza publiczności lub zdolność poszczególnych widzów do „zwracania uwagi” (1977, 4). Reklamodawcy kupują towary publiczności od firm medialnych, a członkowie publiczności następnie pracują dla reklamodawców, ucząc się „kupowania poszczególnych »marek« produktów konsumenckich, i odpowiedniego wydawania swoich dochodów”, a więc „stwarzania popytu” $(1977,6)$.

Smythe próbował zatem jednocześnie przekierować ekonomię polityczną komunikacji raczej w stronę rozważań nad utowarowioną publicznością, niż mediów czy kulturalnych towarów, a teorię komunikacji raczej w stronę rozważań nad pracą publiczności czy pracownikami publiczności, niż w stronę publiczności rozumianej jako masa konsumentów. W pracach poświęconych ekonomii politycznej utowarowionej publiczności, począwszy od Smythe'ego aż do dziś specyfika pracy publiczności została jednak zagubiona. W rezultacie, jak twierdzę, jeden z podstawowych aspektów komunikacji jako kapitału, to znaczy procesu ludzkiej komunikacji zamienionego w proces cyrkulacji i akumulacji kapitału, pozostał nieporuszony: wyzysk pracy publiczności.

By zrozumieć czynności publiczności w obszarze konsumpcji kultury na zasadach stosunku zachodzącego pomiędzy kapitałem a praca, te czynności muszą zostać również zrozumiane jako część procesu produkcji. Smythe nie zrobił jednak tego kroku, mimo że skonceptualizował czynności publiczności jako pracę i otworzył drogę do rozważań na tym, jak kapitał cyrkuluje i akumuluje się, wyzyskując pracę publiczności. Punktem wyjścia Smythe'ego był towar, który w tym przypadku określił on jako publiczność, czy, mówiąc 
bardziej konkretnie, zdolność ludzi do wykonywania czynności związanych z byciem publicznością. Dla Smythe’ego czynności publiczności były rodzajem pracy, typem pracy komunikacyjnej. To, co było na ogół postrzegane jako konsumpcja produktów kultury przez członków publiczności - na przykład oglądanie programów telewizyjnych czy czytanie artykułów w gazetach - dla Smythe'ego było pracą ideologii czy produkcją świadomości (Smythe 1978, 121, 125). Smythe rozważał specyficzny charakter pracy publiczności czy też „usługi wykonywanej dla reklamodawcy przez członków opłaconej publiczności” (Smythe 1977, 6), jako pracę polegająca na „zwracaniu uwagi” wykonywaną dla reklamodawców jako część procesu marketingowego: „,członkowie publiczności (...) uczą się kupować poszczególne »marki« produktów konsumenckich i odpowiedniego wydawania swoich dochodu" $(1977,6)$. Praca publiczności to czynność „zwracania uwagi”, za pomocą której członkowie publiczności „ucza się kupować”; produktem pracy publiczności jest zatem popyt. Smythe doszedł do wniosku, że praca publiczności zrównuje się z ,wykonywaniem zasadniczej usługi marketingowej dla reklamodawców” (1977, 6) jako ,agent marketingowy spod znaku »zrób to sam«" (1978, 121). Smythe nie poszedł jednak dalej w opracowaniu pojęcia pracy publiczności. Utrzymywał, że konsumpcja kultury przez członków publiczności powinna być postrzegana jako praca ideologii bądź produkcja świadomości, a następnie przeszedł do teoretyzowania, jak praca publiczności została utowarowiona. Innymi słowy, dążył więc do skonstruowania ekonomii politycznej utowarowionej publiczności. Brak dalszych prób rozwijania koncepcji pracy publiczności przez Smythe’ego zaowocował w konsekwencji zasadniczymi błędami w jego teorii ekonomii politycznej utowarowienia publiczności i wyzysku tej pracy.

Dla Smythe’ego istotny związek pomiędzy czynnościami publiczności a akumulacją kapitału istniał w ogólnej sferze konsumpcji, stąd też brało się jego zainteresowanie reklamą i zarządzaniem popytem. Twierdził, że masowe media ułatwiają zarządzanie popytem, ponieważ produkują i sprzedaja reklamodawcom wielorakie publiczności jako towary. W ekonomii politycznej masowej komunikacji Smythe'ego to „zarządzanie popytem”, a nie komunikacja jest rzeczywistym procesem zachodzącym podczas konsumowania reklam przez członków publiczności. Pominął on jednak czynności publiczności będące konsumpcją niereklamowych treści. Wychodząc od rozumienia komunikacji jako kapitału, a zarazem odchodząc od zainteresowania Smythe'ego tym, jak masowe media ułatwiaja (bardzie „ekonomicznie” niż po prostu „ideologicznie”) funkcjonowanie monopolistycznego kapitału, „przełomowym pytaniem” staje się nie to: „Co jest forma towarowa masowo produkowanej i wspieranej przez reklamodawców komunikacji?” (Smythe 1977, 2), ale raczej, jak kapitaliści przywłaszczają wartość z procesów komunikacyjnych? W jaki sposób komunikacja traktowana jest jako kapitał? Dlaczego procesy komunikacji postrzegane mogą być jako procesy cyrkulacji i akumulacji kapitału? Choć publiczność jest tylko jednym z elementów układanki Smythe'go, to podkreślić trzeba, że jest w niej elementem ważnym, a moim zdaniem wręcz najważniejszym. 
Sut Jhally i Bill Livant zaproponowali jedną z dwóch najważniejszych alternatyw dla ekonomii politycznej utowarowionej publiczności Smythe’ego. W tekście opublikowanym dziesięć lat po ukazaniu się artykułu Smythe'go podjęli oni próbę zbadania pojęcia pracy publiczności i określenia wartości, jaką ma ta praca dla kapitału ${ }^{4}$. Mimo tego Jhally i Livant nie wykroczyli w większym stopniu poza rozważania Smythe'ego nad specyfiką pracy publiczności, w związku z czym nie zdołali zobrazować tego, w jaki sposób zostaje ona utowarowiana i jak jest wyzyskiwana. Zamiast tego skupili się na czymś, co nazwali „pomnażaniem wartości świadomości publiczności”. Jhally i Livant dowodzili, że praca publiczności jest praca wykonywaną dla firm medialnych, a właściwym towarem wytwarzanym w oparciu o nią jest czas oglądania. Twierdzili również, że członkowie publiczności pracują tylko podczas oglądania reklam i że tylko część tego czasu pracy jest dodatkowym czasem oglądania, który równy jest wartości dodatkowej czy zyskowi (Jhally i Livant 1986, 136). Co więcej, uważali, że oglądanie programów nie jest praca, lecz właśnie formą płacy za czas oglądania reklam, a więc za pracę (1986, 136). Podczas gdy ekonomia polityczna Smythe'ego umiejscawiała utowarowiona publiczność w sferze konsumpcji, ekonomia polityczna Jhally'ego i Livanta umieszcza towar „,czas oglądania” - w sferze cyrkulacji: „Dzięki reklamom, intensywna konsumpcja towarów skraca czas cyrkulacji i obniża koszty magazynowania ponoszone przez kapitalistów produkcyjnych" (1986, 125). Nie postrzegali więc komunikacji jako kapitału samego w sobie, lecz jedynie pokazywali, jak komunikacja umożliwia ogólną akumulację kapitału.

Mimo tak ograniczonego podejścia do ekonomii politycznej komunikacji, Jhally i Livant doszli do kluczowego wniosku, na którym oprę się w trzeciej części niniejszego artykułu. Zwrócili uwagę, że to, co nazwali „kapitałem produkcyjnym” czy „kapitałem-jakocałością", który jako reklamodawca wszystkich wyprodukowanych przez siebie towarów płaci „kapitałowi medialnemu” rentę za dostęp do publiczności (Jhaly i Livant 1986, 125); zatem „kapitał medialny (...) otrzymuje część wartości dodatkowej (zysków) kapitału produkcyjnego” (1986, 125). Autorzy jednak nie wykorzystują kategorii renty jako jednej z kategorii podziału wartości dodatkowej, zapewne dlatego, że teoretyzowanie czynności oglądania jako wykonywania pracy wymagało od nich zajęcia się tym problemem w ramach obszaru produkcji (zob. pierwsza księga Kapitału), w której kapitał przywłaszcza wartość dodatkowa po tym, jak ta została wytworzona przez pracę. Jhally i Livant nie rozważyli zatem możliwości, że przywłaszczenie wartości dodatkowej przez „kapitał medialny” nie zachodzi przez produkcję i że medialni kapitaliści w stosunku do pracowników publiczności ${ }^{5}$ nie są jak kapitaliści

4 Drugą alternatywną wobec projektu Smythe'ego koncepcję ekonomii politycznej stworzyła Eileen Meehan (1984). Praca publiczności została jednak całkowicie pominięta w jej ekonomii politycznej utowarowionej publiczności jako utowarowionych wskaźników.

5 Nie jest tak już jednak w stosunku do pracowników kultury, których kapitaliści zatrudniają do produkcji towarów kultury. Mamy tu bowiem do czynienia ze stosunkami produkcji podobnymi do stosunku pomiędzy 
produkcyjni, ale są raczej podobni do właścicieli ziemskich. Zresztą już na gruncie ich rozważań sugerować mogłoby to użycie pojęcia renty.

Jhally i Livant doszli do jeszcze jednego wniosku, który wykorzystam w kolejnych dwóch częściach. Chodzi o wyartykułowanie tego, co było tylko intuicyjnie obecne u Smythe'a: praca publiczności pociąa za sobą produkcję ,świadomości publiczności”. Jhally i Livant nie sformułowali tej tezy bezpośrednio, poszli jednak wyraźnie dalej niż Smythe w precyzowaniu, jakim rodzajem pracy jest praca publiczności i co właściwie wytwarza. Jhally i Livant stwierdzili w tytule swojego artykułu, że ich zainteresowanie skupia się na „pomnażaniu wartości świadomości publiczności”. Opisali pracę publiczności jako pracę polegającą na oglądaniu, która angażuje „zdolności percepcji” i jest „kierowana przez naszą uwage” (Jhally i Livant 1986, 126). Oglądanie jest więc - jak pisza - kreowaniem znaczenia $(1986,142)$ czy też „procesem świadomości” (1986, 143).

Od początku XXI wieku wielu badaczy wniosło wkład do rozwoju ekonomii politycznej pracy cyfrowej. Zwrócono między innymi uwagę na kwestię pracy komunikacyjnej opartej na mediach cyfrowych, czy też pracy cyfrowej, włączając w to odnowienie ekonomii politycznej utowarowionej publiczności. Mimo to rozwój badań nad pracą cyfrową dokonywał się równolegle z procesem usuwania poza pole zainteresowania ekonomii politycznej komunikacji problematyki pracy publiczności.

Tiziana Terranova (2000) była prawdopodobnie pierwszą badaczka, która podjęła szczegółowe rozważania nad ekonomia polityczna pracy cyfrowej, opisywana przez nia jako „praca darmowa”*. Nie wzięła jednak pod uwage pracy publiczności w postaci konsumpcji kultury. W badaniach nad ekonomia polityczna pracy cyfrowej inwigilacja została uznana za jeden ze sposobów, w który firmy moga zarabiać na cyfrowej komunikacji poprzez zbieranie informacji o komunikacyjnych czynnościach, które w badaniach postrzega się jako pracę cyfrowa (np. Andrejevic 2002, 2007, 2011; Cohen 2008; Fuchs 2011a, 2011b; Kang i McAllister 2011; Manzerolle 2010; McStay 2011). Podstawowe teorie ekonomii politycznej rozwijane w tym paradygmacie proponowały włączanie $w$ obręb ich zainteresowań sprzedaży reklamodawcom danych zebranych dzięki inwigilacji. W ramach różnych dokonań badawczych, szczególnie tych rozwijających nową ekonomię polityczną utowarowionej publiczności, będących kontynuacją oryginalnych pomysłów Smythe'ego, rzekoma sprzedaż użytkowników, prosumentów czy pracowników cyfrowych (lub ich uwagi) reklamodawcom również stała się przedmiotem znacznej liczby badań (np. Fuchs 2010, 2012; Kang i McAllister 2011; Manzerolle

kapitalistami produkcyjnymi a zatrudnianymi przez nich robotnikami, gdzie drudzy wytwarzają wartość dodatkową w procesie produkcji, a pierwsi ją sobie przywłaszczają.

* Przypis od tłumacza: Terranova posługując się pojęciem „free labour”, korzysta z dwuznaczności językowej, której w języku polskim nie da się uzyskać. W kontekście, w jakim pojęcie to funkcjonuje w niniejszym artykule zdecydowałem się na tłumaczenie go konsekwentnie jako „praca darmowa”. 
2010; Napoli 2010). Uważam jednak, że nie ustrzegły się one wielu błędów podobnych do tych obecnych już w ekonomii politycznej zaproponowanej przez Smythe'ego i innych wcześniejszych koncepcjach ekonomii politycznej utowarowionej publiczności. Równie dużym zainteresowaniem badaczy cieszyło się w początkach wieku również przywłaszczenie stworzonej przez użytkowników treści poprzez pracę cyfrową (np. Cohen 2008; Fisher 2012; Fuchs 2010; Terranova 2000). Definiuję to jako wyzysk cyfrowej pracy kulturalnej. Teorie ekonomii politycznej proponowane przez cytowanych autorów prezentowały pogląd, że cyfrowa praca kulturalna jest w istocie wyzyskiwana, nie wskazywały jednak związku pomiędzy takim wyzyskiem a akumulacją kapitału.

Praca, na która pierwszy raz zwrócił uwagę Smythe jako na pracę publiczności i która rozważali również Jhally i Livant, włączając w nią „pracę oglądania” i produkcję „,́́wiadomości publiczności”, w dalszym ciągu wydaje się najtrudniejszym do uchwycenia rodzajem pracy w ramach ekonomii politycznej komunikacji. Ani Smythe, ani Jhally i Livant nie byli wystarczająco konkretni w konceptualizacji pracy publiczności, podczas gdy teoretycy ekonomii politycznej pracy cyfrowej sprawili, że praca publiczności całkowicie zniknęła z pola zainteresowania ekonomii politycznej komunikacji. Żadne z prowadzonych aktualnie badań nie zwróciły uwagi na kluczowy stosunek pomiędzy kapitałem komunikacyjnym a cyfrową praca publiczności - stosunek, który definiuje użytkowników mediów cyfrowych jako konsumentów treści (chociaż są oni często również producentami), a co za tym idzie, umożliwiający bezpośredni lub pośredni wyzysk cyfrowej pracy publiczności ${ }^{6}$. Ten stosunek to kontrola środków produkcji komunikacyjnej wykorzystywanych w procesie konsumpcji kultury.

\subsection{Problem metody}

W tej części omówię zmiany w metodologii, niezbędne dla rozwoju ekonomii politycznej pracy publiczności, będącej teoria komunikacji rozumianej jako kapitał, konsumpcji kultury jako pracy publiczności wewnątrz produkcji komunikacyjnej i stosunku pomiędzy akumulacją kapitału i pracą publiczności jako momentu, w którym kontrola nad czynnościami publiczności może być rozumiana jako kwestia wyzysku. Skupienie się na pracy publiczności wewnątrz teorii ekonomii politycznej wymaga namysłu nad tym, czym są czynności publiczności i jak są one wyzyskiwane przez komunikacyjnych kapitalistów. Konieczne więc są rozważania nad procesem pracy publiczności i sposobem, w jaki proces ten odnosi się do akumulacji kapitału. Smythe $(1978,126)$ podkreślał, że konieczna metoda integrowania czynności publiczności w ekonomię polityczna jest „historyczno-materialistyczna metoda dialektyczna”. We wcześniejszych tekstach argumentowałem, że metoda dialektyczna, będąca zarazem

6 Bardziej szczegółowe omówienie nierozwiniętego pojęcia pracy publiczności u Smythe'a oraz Jhally'ego i Livanta, a także o zjawisku zniknięciu pracy publiczności z ekonomii politycznej pracy cyfrowej zob. Nixon (2013). 
historyczną i materialistyczną, jest konieczną metodą teoretyzowania komunikacji z perspektywy ekonomii politycznej (Nixon 2012). Tutaj rozwinę ten argument w celu skonstruowania metody nadającej się do sformułowania ekonomii politycznej pracy publiczności.

Ekonomia polityczna opisuje „ogólne określenia produkcji na danym szczeblu społecznym” (Marks 1986, 41). Ekonomia polityczna jest nauka „całej sumy” „materialnych warunków życia” czy „stosunków produkcji”. Ekonomia polityczna, jako teoria produkcji w powyższym znaczeniu, wiąże się z tym, co, jak zauważył Karol Marks, klasyczna ekonomia polityczna traktuje jako „ogólnośc” w powiązaniach z innymi aspektami całego sposobu produkcji. Produkcja wytwarza towary dzielone w procesie podziału i formalnie wymieniane pomiędzy jednostkami, które ostatecznie je konsumują.

\begin{abstract}
Produkcja, podział, wymiana, konsumpcja tworzą więc [zdaniem ekonomistów] prawidłowy sylogizm; produkcja stanowi ogólne, podział i wymiana - szczególne, konsumpcja - jednostkowe, które zamyka całość. (...) Produkcję określają ogólne prawa przyrody; podział - przypadek społeczny (...) ; wymiana znajduje się pomiędzy produkcja a podziałem jako formalnie społeczny ruch, zaś końcowy akt - konsumpcja, ujmowana nie tylko jako punkt docelowy, lecz również jako cel ostateczny - leży właściwie poza ekonomią, wyjąwszy w tej mierze, w jakiej oddziaływa z powrotem na punkt wyjścia i wszczyna cały przebieg na nowo (Marks 1986, 44).
\end{abstract}

Marks krytykuje „płytką” koherencję „prawidłowego sylogizmu” klasycznej ekonomii politycznej między ogólnością produkcji, szczególnością podziału i wymiany a jednostkowością konsumpcji. Proponuje wobec tego dialektyczną relację pomiędzy produkcją, podziałem, wymianą i konsumpcją jako „członami jednej całości, różnicami w obrębie jedności”, momentami „organicznej”, a nie sylogistycznej całości, pomiędzy którymi „zachodzi wzajemne oddziaływanie” (Marks 1986, 51-52). Jak zauważa jednak David Harvey, również Marks do pewnego stopnia stosował się do tego sylogizmu i jego płytkiej koherencji (Harvey 2012, 10), podejmując próbę określenia praw ruchu kapitalizmu. Biorąc pod uwagę, że celem Marksa było „wykrycie ekonomicznych praw ruchu” społeczeństwa kapitalistycznego, „praw natury” kapitalistycznego sposobu produkcji (Marks 1951, 6), łatwo dostrzec, dlaczego utknął w swoich rozważaniach na poziomie ogólności. Jak sam odpowiadał tym, którzy krytykowali klasyczną ekonomię polityczną za przesadne akcentowanie produkcji: zadanie polega na „pojmowaniu realnych stosunków”, a nie na „dialektycznym pogodzeniu pojęć” (Marks 1986, 44). To właśnie produkcję „określają ogólne prawa przyrody” (1986, 44), które mogą zostać zrozumiane tylko teoretycznie poprzez siłę abstrakcji. Nawet jeśli pomyślimy o sylogizmie dialektycznie, widząc w każdej kategorii moment organicznej całości czy totalności, wciąż „produkcja dominuje” nad innymi momentami $(1986,51)$. 
Staram się wobec tego sformułować ekonomię polityczną komunikacji, która wyjaśnia prawa ruchu kapitalistycznej produkcji komunikacyjnej, będącą teorią tego, jak kapitał jest akumulowany przez komunikację. Z tego też powodu zamierzam skupić się na ogólności produkcji w formie produkcji komunikacyjnej, jak również w większym stopniu włączyć aspekty dystrybucji i konsumpcji do teorii ekonomii politycznej, posługując się zarówno tym, co użyteczne z sylogizmu opisanego powyżej, jak i Marksowską dialektyczną koncepcja stosunku produkcja-konsumpcja i produkcja-dystrybucja, a następnie rozwojem tych relacji wewnątrz teorii ekonomii politycznej opisanych przez Harveya w Limits to Capital (Harvey 2006).

Harvey (2012) wyjaśnia, jak w praktyce działa Marksowska metoda jako metoda ekonomii politycznej, co samo w sobie wymaga pogodzenia Marksowskich historycznych, materialistycznych dialektycznych pryncypiów produkowania wiedzy ze „słabym sylogizmem” oraz skupienia się na „ogólności” produkcji ugruntowanej w klasycznej ekonomii politycznej. Jak wskazuje Harvey, Marks chciał kontynuować „naukę” ekonomii politycznej, pragnąc jednocześnie skonstruować ekonomię polityczną fundamentalnie przeczącą utopijnej wizji klasycznej ekonomii politycznej, ukazując dystopijną logikę praw ruchu kapitalistycznego sposobu produkcji (Harvey 2012, 6-7; 2010, 52-53). Czyniąc to, Marks ściśle (być może nawet sztywno) trzyma się „prawidłowego sylogizmu” klasycznej ekonomii politycznej, w której produkcja jest ogólnością i co za tym idzie, przedmiotem teoretyzowania, jeśli tylko za cel przyjmie się stworzenie wiedzy o prawach ruchu kapitalistycznego sposobu produkcji (Harvey 2012, 6). Marks w swoim procesie abstrahowania usiłuje spojrzeć na ogólność produkcji możliwie wąsko, jednocześnie w dalszym ciąu posługując się „organicznym myśleniem i dialektyczno-relacyjna analizą" w celu stworzenia własnej ekonomii politycznej $(2012,10)$. Harvey wyjaśnia to następująco: „pominięcia są niemal zawsze uzasadniane na gruncie tego, że nie znajdują się w polu ogólności, którym Marks jest wyłącznie zainteresowany” (2012,11).

W trzeciej części artykułu, formułując ekonomię polityczną pracy publiczności, próbuję zastosować do produkcji komunikacyjnej opisaną powyżej metodę tak, aby móc pogodzić „słaby sylogizm” i związane z nim skupienie na ogólności produkcji z historycznomaterialistyczną dialektyczną metodą teoretyzowania. Następnie próbuję wzbogacić ekonomię polityczną komunikacji jako teorię ogólności produkcji komunikacyjnej poprzez integrację w dialektyczny sposób szczególności podziału, a nawet jednostkowości konsumpcji, a także, jeśli to tylko możliwe, pojąć „realne stosunki” kapitalistycznej produkcji komunikacyjnej (Marks 1986, 44). W tym celu nawiązuję do Marksowskich rozważań nad dialektycznością stosunków pomiędzy produkcją a innymi „momentami” - podziałem, wymianą i konsumpcja. Jednak zanim to zrobię, usytuuję najpierw pojęcie pracy publiczności tak, by mogło służyć za podstawę teorii ekonomii politycznej. W tym celu konieczne będzie uwzględnienie wkładu 
Raymonda Williamsa w rozwinięcie historyczno-materialistycznej dialektycznej metody teoretyzowania komunikacji jako produkcji.

\subsection{Odnowienie projektu Raymonda Williamsa: rozważania nad produkcją komunikacyjną}

Sięgnięcie do koncepcji Williamsa jest niezbędne dla dalszego rozwoju ekonomii politycznej pracy publiczności, ponieważ na jej gruncie sproblematyzowano „środki komunikacji” jako „środki produkcji”, a komunikację i kulturę jako ludzki proces produkcji (Williams 1980a, 1980b, 1981). Co najważniejsze, ludzka aktywność produkcyjna stanowi jądro Williamsowskiej metody rozważań: „Społeczeństwo nie jest do końca gotowe na bycie poddanym analizie, dopóki wszystkie jego części nie zostaną wzięte pod uwage” (1980a, 44). Praktyki kulturowe, jak podkreślał, są aspektem „ogólnego procesu społecznego” (1980a, 44). W obrębie tego, co Williams (1980b, 53) nazywał „całością historycznego procesu społecznego i materialnego” (rozumiejąc przez to ludzką egzystencję), wytwarzane są zarówno kultura, jak i świadomość. Nawiązując do Marksa (1986), Williams (1980a, 46-49) naciskał na rozważanie ludzkich czynności przede wszystkim jako procesów produkcji, a nie konsumpcji. Jak uważał bowiem, właśnie próby analizy praktyk komunikacyjnych i kulturowych przez pryzmat konsumpcji pociagały ze sobą największe spośród porażek odnotowanych na tym polu badań.

Dan Schiller (1996) dostrzegł w pracach Williamsa podstawę dla rozwoju „spójnej ramy konceptualnej” teoretyzowania komunikacji. Schiller podsumował swoją historię teorii komunikacyjnej stwierdzeniem, że Williams wyznaczył konieczną drogę dla przyszłych badań: drogę do ujednolicenia komunikacji pod pojęciem pracy, a więc tym samym drogę do teoretyzowania komunikacji jako pracy. Spróbuję oprzeć się na twierdzeniu Schillera, ukazując produktywność proponowanego przez niego wznowienia projektu Williamsa, szczególnie zwracając uwagę na wartość, jaką ma ono przy rozwijaniu projektu ekonomii politycznej pracy publiczności. Uzasadnię zarówno potrzebę takiego teoretycznego rozwiązania, jak i spróbuję dostarczyć niezbędnych środków, dzięki którym rozwój ten może się dokonać.

Po pierwsze, uważam, że najważniejszym wkładem Williamsa do ekonomii politycznej pracy publiczności jest postawienie problemu „bazy i nadbudowy w marksistowskiej teorii kulturowej”. Zamiast ujmować kulturę i czynności kulturalne jako aspekty nadbudowy determinowanej przez bazę, jak ma to często miejsce w teorii marksistowskiej, Williams podkreślał konieczność ponownego rozważenia bazy w celu zrozumienia „realiów procesu kulturowego" (Williams 1980a, 33, podkr. - BN). Wskazywał, że Marks kładł nacisk na „czynności produkcyjne”, a tym samym bardziej na proces produkcji, niż na statyczna „bazę” (1980a, 34-35). Produkcja kulturalna zdecydowanie nie znajduje się więc poza ogólnym procesem produkcji, a praktyki kulturalne składające się na kulturowy proces produkcji nie moga być postrzegane jako części „nadbudowy” tylko dlatego, że są kulturowe. Odkrycie 
„natury praktyki, a następnie jej warunków” (1980a, 47) umożliwia zatem teoretyzowanie praktyk kulturalnych raczej jako czynności produkcyjnych, niż po prostu konsumpcji.

Teoretyzowanie kultury poprzez spoglądanie na „warunki praktyki” (Williams 1980a, 48) okazuje się przydatne w odniesieniu do metody ekonomii politycznej, którą opisałem powyżej. Ta metoda teoretyzowania kultury może być rozszerzona o bezpośredni produktywny wkład w ekonomię polityczną pracy publiczności, dzięki wzbogaceniu jej przez rozważania Williamsa nad „siłami wytwórczymi”, a w szczególności nad środkami komunikacji jako środkami produkcji. W przeciwieństwie do wcześniejszej koncepcji sił wytwórczych jako „produkcyjnych” i z definicji wykluczających rzekome aspekty nadbudowy, takie jak środki komunikacji czy inne środki produkcji kulturalnej, Williams twierdził, że siły wytwórcze sa „wszystkie razem i z osobna środkami wytwarzania i odtwarzania realnego życia” (Williams 1989, 149). Możliwym zatem jest zrozumienie, poprzednio unikanego czy omijanego, „materialnego charakteru procesu wytwarzania (...) porządku kulturalnego” $(1989,152)$ jako „rzeczywistej praktyki, elementu całościowego materialnego procesu społecznego (...) różnorodnych i zmiennych praktyk produkcyjnych, powiązanych z określonymi warunkami i dążeniami” (1989, 154; podkr. - BN). Można zatem stwierdzić, że koniecznym jest ,spojrzenie na nasze rzeczywiste czynności bez przyjmowania z góry, że tylko niektóre z nich są materialne"(1989, 155). To właśnie w duchu tego stwierdzenia ekonomia polityczna pracy publiczności może być rozwijana środkami historyczno-materialistycznej metody dialektycznej. Szczególne opracowanie „środków komunikacji, jako środków produkcji” wnosi istotny wkład do tego procesu.

Williams jasno i wprost twierdził, że „środki komunikacji same są środkami produkcji” (1980b, 50), otwierając w ten sposób wiele możliwości przed metodą teoretyzowania ekonomii politycznej komunikacji. Uważał w istocie, że niezbędny jest rodzaj „teoretycznej rewizji (...) definicji sił wytwórczych" (Williams 1989, 225). Znaczenie tej perspektywy zostało jednak pominięte przez jednego z niewielu badaczy, którzy ostatnio zajmowali się tą problematyką (zob. Hebblewhite 2012). Pojęcie „środków produkcji” jest i centralnym pojęciem ekonomii politycznej, lecz Williams nie starał się ustalić, jak środki produkcji komunikacyjnej powinny być włączone do ekonomii politycznej komunikacji za pomocą historyczno-materialistycznej metody dialektycznej. Zamiast tego badal je historycznie i tym samym zaproponowal nowe podejście do ekonomii politycznej komunikacji: kategorię „produkcji komunikacyjnej”. W ostatniej części tego artykułu spróbuję włączyć środki produkcji komunikacyjnej do ekonomii politycznej pracy publiczności. Tutaj zaś pominę dyskusję nad tą prostą, ale stwarzająca wiele możliwości perspektywą, gdyż sam Williams nie rozważał jej dalej w kategoriach teorii ekonomii politycznej.

Podczas gdy Williams sugerował potrzebę „historii produkcji komunikacyjnej” (Williams 1980b, 53-54), dla mnie istotnym jest również teoretyzowanie produkcji 
komunikacyjnej. Innymi słowy, interesuje mnie rozwinięcie ekonomii politycznej komunikacji za pomocą środków metody materialistycznej proponowanych przez Williamsa. Skoro chcę skupić się na rozwinięciu ekonomii politycznej pracy publiczności, powinienem spróbować teoretyzować pracę publiczności w ramach kapitalistycznej produkcji komunikacyjnej. Robiąc to, zamierzam odpowiedzieć na wezwanie Smythe'ego w sprawie historyczno-materialistycznej metody dialektycznej, nadającej się do teoretyzowania komunikacji dzięki przyswojeniu Marksowskiej metody i użyciu jej do teoretyzowania produkcji komunikacyjnej i pracy publiczności z wykorzystaniem perspektywy Williamsa. W ten sposób sproblematyzuję komunikację jako kapitał i określę naturę wyzysku pracy publiczności. Sama koncepcja Williamsa jest pomocna natomiast w jeszcze jednym, niezbędnym elemencie mojej konceptualizacji: teoretyzowaniu komunikacji jako pracy.

\section{Doprecyzowanie pracy publiczności: teoretyzowanie procesu pracy publiczności jako wytwarzania znaczenia przez konsumpcję kultury}

W swojej teorii utowarowionej publiczności Smythe opisał teoretyczny „słaby punkt” w „produkcji ideologii” (Smythe 1978, 121) i zlokalizował go w błędzie metodologicznym. Podkreślał, że metoda dialektyczna materializmu historycznego jest potrzebna w celu ukazania teorii „produkcji ideologii”. Argumentował, że metoda prowadziłaby do teorii członków publiczności, wykonujących samodzielnie pracę polegająca na produkcji ich własnej świadomości jako świadomości konsumentów, a co za tym idzie, produkujących „popyt” na towary, podczas gdy ich zdolność wykonywania tej pracy stanowi element wymieniany jako utowarowiona publiczność, która z kolei jest wytwarzana i sprzedawana przez przemysł komunikacyjny, a następnie kupowana przez reklamodawców (Smythe 1977; 1978). Odsuwając na bok moją wcześniejszą krytykę tej teorii ekonomii politycznej, twierdzę, że szukając stosunku pomiędzy praca publiczności a produkcją ideologii, Smythe proponuje ważny punkt wyjścia, który może być dalej rozwijany jako podstawa teorii procesu pracy publiczności.

Praca publiczności jest rodzajem pracy uwikłanej w produkcję ideologii, a więc, ogólnie ujmując, świadomości publiczności. Smythe zaproponował tylko jej mglisty opis, przedstawiając ją jako proces zwracania uwagi, „uczenia się kupowania” i „uczenia się teorii i praktyki konsumeryzmu" (Smythe 1977, 4, 6, 20). Jhally i Livant opisali go nieco konkretniej, wskazując, że przybiera on postać tworzenia znaczenia i stanowi „proces świadomości” (Jhally i Livant 1986, 142-143). W oparciu o Williamsowskie (1980) pojęcie „produkcji komunikacyjnej" i o to, co Schiller (1996) z niego wywodzi, przedstawiając je jako podstawę teoretyzowania komunikacji jako pracy, możliwe jest myślenie o procesie pracy publiczności jako o procesie odbywającym się wewnątrz produkcji komunikacyjnej, a zatem procesie, który 
coś produkuje. Trzeba więc odpowiedzieć na pytanie: jaka jest natura procesu pracy publiczności?

Proces, który opisywałem tutaj jako pracę publiczności, jest również często przedstawiany po prostu jako konsumpcja, co sugerowałoby, że koniecznym jest poważne potraktowanie „pojedynczości” konsumpcji, w rozumieniu, w jakim zostało to nakreślone we wprowadzeniu do Zarysu krytyki ekonomii politycznej (Marks 1986), w celu steoretyzowania procesu pracy publiczności. By móc następnie rozwinąć tę teorię procesu pracy publiczności w ekonomię polityczną pracy publiczności, konieczne jest połączenie „pojedynczości” konsumpcji zarówno z „ogólnością" produkcji komunikacyjnej, jak i „partykularnością" podziału. Tymi dalszymi dwoma teoretycznymi rozwinięciami zajmę się w części trzeciej. Tutaj spróbuje rozwinać podstawową teorię procesu pracy publiczności, określając, po pierwsze, jak teorie czynności publiczności, jako tworzenie znaczenia, przyczyniaja się do ponownej konceptualizacji procesu pracy publiczności, przekraczającej teorię pracy publiczności w ekonomii politycznej utowarowionej publiczności; po drugie, pod jakim względem teoria stosunku pomiędzy utowarowieniem kultury a produkcja ideologii sformułowana przez Horkheimera i Adorna stanowi wkład do teorii procesu pracy publiczności, i po trzecie, jak Marksowski opis procesu pracy z pierwszej księgi Kapitału może być użyty jako szablon dla teorii procesu pracy publiczności.

\subsection{Czynności publiczności jako wytwarzanie znaczenia}

Esej Stuarta Halla „Kodowanie i dekodowanie” daje dobry punkt wyjścia do wzbogacenia teorii pracy publiczności poprzez włączenie w nią koncepcji publiczności „wytwarzającej znaczenie”. Dzieje się tak pomimo tego, że esej ten napisany został dokładnie przeciw teoretycznemu zastosowaniu proponowanemu przeze mnie, wyraźnie rozróżniając to, co Hall nazywa „produkcją dyskursywną” od „innych typów produkcji” (Hall 1987, 59; Schiller 1996, 149). Hall (1987) zaproponował zrewidowaną teorię procesu „masowej komunikacji” oraz stosunków pomiędzy branżami komunikacyjnymi i ich publicznościami, ujmując ją w języku semiotyki i wykorzystując metodę strukturalistyczną (teoretyzując na przykład „przedstawienia” pomiędzy „względnie niezależnymi” „momentami determinującymi” [Hall 1987, 59]). W procesie, który opisał Hall, praca publiczności może być postrzegana więc jako „dekodowanie”.

W ramach całego procesu „kodowania” i „dekodowania” w „produkcji dyskursywnej” istnieje możliwość „walki o znaczenia” (Hall 1987, 65) właśnie z powodu konieczności „odkodowania” znaków. Innymi słowy, publiczność musi pracować, by wyprodukować znaczenie z konsumowanych przez siebie znaczeń. Znaki z natury są „wieloznaczne” (1987, 66) i wewnątrz „konotacyjnego” aspektu procesu „odkodowywania” nie są trwałe, ale maja „bardziej otwarty charakter” i są „bardziej podatne na przekształcenia” (1987, 66). Jeśli „dekodowanie” „kieruje się (...) własnymi zasadami” (1987, 68), „nie musi zachodzić 
odpowiedniość” pomiędzy „kodowaniem” a „dekodowaniem”, a więc dla członków publiczności znaczeniem jest to, co sami produkuja, pomimo pewnych strukturalnych limitów determinowanych przez sam „kod” $(1987,66)$ i mimo że dalsze „dekodowanie” przekazu jest zawsze możliwe za pomoca „,wynegocjowanego” czy nawet „opozycyjnego” kodu (1987, 70_ 71).

Podczas gdy dla Halla proces „kodowania” w produkcji przekazu jest „procesem pracy” (Hall 1987, 60) i składa się z „zabiegów interpretacyjnych” (1987, 67), czynności publiczności w postaci „odkodowywania” nie są wcale opisane jako praca. Co więcej, sama „produkcja dyskursywna” różni się według niego od innych typów produkcji, ponieważ jej produkty („nośniki znaków” zawierające znaczenie) przyjmują inne „,formy dyskursywne”, jako że cyrkuluja poprzez proces komunikacyjny i musza funkcjonować w ramach „formalnych reguł języka” (1987, 58-60). A jednak uwaga, jaką Hall zwraca na proces, w ramach którego publiczność produkuje znaczenie, posługując się przy tym „zakodowanymi” znaczeniami przekazów wyprodukowanych przez przemysł komunikacyjny, otwiera możliwość skupienia się na procesie, w którym członkowie publiczności produkują znaczenie, wykonując czynność konsumpcji kultury. Hall oddzielił znaczenie od samego przekazu, dlatego też członek publiczności nie jest wyłącznie odbiorcą znaczenia zawartego w przekazie - taka perspektywa rzecz jasna prowadzi do poszukiwania wiedzy o „efektach” wywieranych na publiczności przez przekaz - ale raczej deszyfrantem znaczenia, co następnie prowadzi do poszukiwania wiedzy o znaczeniach wytworzonych przez publiczność. Jednym z takich podejść jest koncepcja „Czynnej publiczności”.

Możliwy staje się więc dalszy postęp na drodze rekonfiguracji procesu pracy publiczności dzięki wzbogaceniu koncepcji pracy publiczności o perspektywę „czynnej publiczności”. Związek z teorią „czynnych przekształceń” znaczenia, możliwych w procesie „dekodowania” Halla, jest ewidentny w teorii Johna Fiske’ego, opisującej publiczność jako „Czynną" w tym sensie, że jest ona „społecznym” a nie „obecnym w tekście” podmiotem: „Współczesny widz telewizyjny jest przede wszystkim podmiotem społecznym. Ta społeczna podmiotowość jest bardziej istotna w konstruowaniu znaczeń niż produkowana tekstualnie podmiotowość, która istnieje wyłącznie w momencie czytania" (Fiske 1987, 62). Fiske podążając dalej za tym tokiem myślenia, twierdzi, że należy skupić się w analizie na „szczelinach i przestrzeniach, które otwierają telewizję na znaczenie preferowane nie przez strukturę tekstualną, ale które są raczej wynikiem społecznych doświadczeń czytelników” (1987, 64). Teoria „czynnej publiczności” „wytwarzającej znaczenia” sprawia, że możliwe jest wzbogacenie teorii pracy publiczności poprzez wyszczególnienie procesu pracy i jego wytworu. Podstawowa teoria publiczności wytwarzającej znaczenie to taka, która musi zostać zaadaptowana do teorii ekonomii politycznej w postaci teorii pracy publiczności. Spostrzeżenie przez Fiske'ego tego, ,jak wytwarzane są znaczenia przez czynne czytanie przez publiczność”, 
okazuje się przydatne w procesie dalszego rozwijania teorii pracy publiczności. Produktem czynności publiczności są „znaczenia”, a zatem praca publiczności jest procesem oznaczania poprzez konsumpcję kultury.

\subsection{Czynność publiczności jako produkcja ideologii}

Esej Maksa Horkheimera i Theodora Adorna „Przemysł kulturalny: Oświecenie jako masowe oszustwo" stanowi kolejny istotny wkład do ekonomii politycznej pracy publiczności. Możliwe jest to dzięki rozważaniom nad stosunkiem między utowarowioną kulturą a produkcją ideologii. Ich teoria produkcji świadomości nie jest teorią ekonomii politycznej, ale może być podstawą do rozwijania tej drugiej, ponieważ umożliwia wskazanie istotnych aspektów pracy publiczności. Horkheimer i Adorno nie wspominają o czynnościach publiczności jako pracy i skupiają się raczej na tym, jak przemysł kulturalny wytwarza ideologię. W tym sensie istnieje pewne zagrożenie, że pojęcie publiczności zagubi się w procesie, który opisują. Ich argumentacja cechuje się pewną zawiłością, z której można jednak wyprowadzić określone korzyści dla ekonomii politycznej pracy publiczności: nie jest tak, że utowarowienie kultury samo w sobie powoduje „masowe oszustwo”; istnieje szczególny stosunek między treścią kultury a świadomością wytwarzaną przez konsumentów tej kultury.

Przemysł kulturalny - przemysł, który masowo produkuje kulturę, to znaczy kolektywny system produkcji kulturalnej składający się z przemysłów mediów masowych wytwarza pewnego rodzaju ,jednolitość” (Horkheimer i Adorno 2010, 123). Jednolitość, którą zainteresowani są Horkheimer i Adorno zasugerowana jest w podtytule eseju: „Oświecenie jako masowe oszustwo". Autorzy są zaniepokojeni tym, co stanie się z treścią myśli, jeśli kultura zostanie utowarowiona, zwłaszcza jeśli w istocie produkcja kulturalna jest masowa produkcja kulturalnych towarów. W kulturze pozbawionej źródła myśli krytycznej, której możliwość istnienia zakładaja Horkheimer i Adorno, istnieje raczej masowe oszustwo, a nie oświecenie. Szczególną obawą autorów nie jest samo istnienie kultury wytwarzanej przez przemysł kulturalny w postaci masy towarów, ale raczej to, w jaki sposób odnosi się ona do społecznej świadomości, to znaczy masowego oświecenia lub masowego oszustwa. Jak podsumowuja, kultura produkowana przez przemysł kulturalny jest podstawa produkcji masowego oszustwa, „ideologii” reprodukującej status quo pod postacią wolności wyboru. W tym tkwi istota dialektyki oświecenia, w ramach której szerszy dostęp do kultury, ze względu na jej treść, produkuje raczej masowe oszustwo niż masowe oświecenie.

„Doprowadzona gwałtem uniformizacja” produkcji kulturalnej przez przemysł kulturalny zubaża „materiał estetyczny” kultury, ponieważ proces produkcji jest masowa produkcją przemysłowa, która syntetyzuje treść produktów kultury, mogących być zamiast tego indywidualnymi wyrazami kulturalnymi (Horkheimer i Adorno 2010, 126). Jeszcze przed powstaniem przemysłu kulturalnego produkcja kulturalna nie była ujednolicana w ten sam 
sposób. Nie przedstawiała „fałszywej jedności tego, co ogólne, i tego, co szczegółowe” (2010, 123), a co za tym idzie, umożliwiała szczegółom emancypację z produktów kulturalnych, których były częścia, co z kolei pozwalało partykularności każdego indywidualnego dzieła jako „szczegółowi (...), jako nieokiełznanej ekspresji, agentowi opozycji, buntować się przeciw organizacji” (2010, 128). Szczegóły te są jednak teraz ujarzmiane i podporządkowywane totalności formułki produkcji przemysłu kulturalnego: „formułce, zastępującej dzieło” (2010, 128). Produkty przemysłu kulturalnego generuja zatem „zubożenie wyobraźni i spontaniczności”, jako że konsumentom tych produktów zakazuje się wszelkich aktywności myślowych, jeśli tylko nie chca przegapić wszystkich efektów, będących jednak częściami formułki całości (2010, 129). „Każda poszczególna manifestacja przemysłu kulturalnego nieuchronnie reprodukuje ludzi jako to, czym stali się za sprawą całego przemysłu kulturalnego. Nad tym, by reprodukcja prosta ducha nie przeszła w reprodukcje rozszerzona, czuwają wszyscy agenci (przemysłu kulturalnego - przyp. tłum.) (...)” (2010, 129). Bycie zabawianym przez produkty przemysłu kulturalnego oznacza wyłącznie ucieczkę „przed ostatnia myślą o oporze” „złej rzeczywistości”, wyzwolenie „od myślenia jako od negacji” (2010, 146).

Podczas gdy obietnica masowego oświecenia wydaje się nieodłącznie związana ze zwiększoną dostępnością do kultury, stanowiącą rezultat masową produkcji przemysłu kulturalnego („Konsumenci mogą się cieszyć, że jest tyle do oglądania i słuchania” [2010, 162]), treść tej kultury, jak widzieliśmy w powyższym fragmencie, gwarantuje, że tego rodzaju oświecenie nie nastapi. Jednocząca monotonia kultury wyprodukowanej przez przemysł kulturalny skutkuje monotonią społecznej świadomości. „Wszyscy mogą swobodnie tańczyć i oddawać się uciechom (...) Ale wolność w wyborze ideologii (...) okazuje się we wszystkich dziedzinach wolnością do zawsze tego samego" (2010, 168). Jasnym jest, że dla Horkheimera i Adorna istnieje związek pomiędzy kulturą a świadomością wytwarzaną przez jej konsumpcję. Biorąc pod uwagę, że czynności publiczności są rzecz jasna konsumpcją kultury, jest ona zatem zasobem używanym w procesie produkcji komunikacyjnej oznaczania poprzez jej konsumpcję. Kontrola nad kultura jest zarazem środkiem, za pomocą którego kapitał może kontrolować również czynności publiczności.

Wage zarówno koncepcji Horkheimera i Adorna, jak i teorii czynnej, wytwarzającej znaczenie publiczności dla procesu pracy publiczności i ekonomii politycznej pracy publiczności, dostrzeżemy, gdy umieścimy te teorie w ramach ekonomii politycznej.

\subsection{Czynność publiczności jako praca: Marksowska teoria procesu pracy}

Marksowska teoria procesu pracy z pierwszej księgi Kapitału daje do ręki szablon, pozwalający dokonać rekonceptualizacji procesu pracy publiczności, rozwiniętej powyżej w proces pracy publiczności, który może posłużyć jako podstawa jej ekonomii politycznej. Proces ludzkiej pracy w swoim najprostszym znaczeniu niezależności „od jakiejkolwiek określonej formy 
społecznej” składa się z trzech elementów: „celowej działalności, czyli samej pracy, jej przedmiotów i środków” (Marks 1951, 188-189). Mamy zatem trzy pojęcia: pracę, przedmiot pracy i środek pracy. Proces pracy publiczności, podobnie oddzielony od określonej formy, którą przybiera w kapitalizmie, może być wpierw teoretyzowany jako proces obejmujący pracę publiczności, przedmiot(y) pracy publiczności i środek/środki pracy publiczności.

W tym sensie praca publiczności to po prostu czynności poszczególnych jej członków, angażujących się w różne działania konsumpcji kultury. Przedmiot pracy publiczności jest zazwyczaj postrzegany jako konsumowany przez jej członków: kultura czy oznaczone przedmioty stworzone po to, by skonsumować ich znaczenie (włączając w to reklamy). Niemniej mówienie o „pracy publiczności” faktycznie oznacza założenie już z góry pracy w określonym stosunku społecznym i, co więcej, specyficznie kapitalistyczną produkcję komunikacyjną. Traktowanie pracy publiczności jako zasadniczego rodzaju ludzkiej pracy, niezależnego od „określonej formy społecznej”, oznacza reifikację przemysłu kulturalnego, który najpierw z poszczególnych indywiduów wytwarza członków publiczności. Przedmiot pracy publiczności w postaci „kultury” zakłada istnienie produkcji czegoś, co może być rozpoznane jako oddzielny produkt kultury; zakłada istnienie przemysłu kulturalnego. Niezbędne jest dalsze abstrahowanie od pracy publiczności, by móc zobaczyć, że jest ona aspektem bardziej ogólnej pracy oznaczania czy wytwarzania znaczenia przez konsumpcję znaczenia. Przedmiotem tej pracy jest zatem wszystko, co postrzegane przez zmysły i „konsumowane” w myślach?

By jednak nie wykraczać daleko poza ramy ekonomii politycznej komunikacji, wracam do już społecznie określonego procesu pracy publiczności, aby zająć się nim w możliwie najbardziej abstrakcyjny sposób, mając jednak na uwadze konieczne zastrzeżenie, które poczyniłem powyżej. Przedmiotem pracy publiczności jest zatem to, co nazywam kultura, przez którą rozumiem każdy znaczący przedmiot, który przez każdego i każdą może zostać rozpoznany jako wytwór kultury. Posługuję się „kulturą” w tym samym szerokim znaczeniu, w jakim Marks posługiwał się „przyrodą”, opisując proces ludzkiej pracy w jego najbardziej fundamentalnym, a zatem i abstrakcyjnym sensie: „Praca jest przede wszystkim procesem zachodzącym między człowiekiem a przyrodą”, w którym człowiek „przyswaja sobie materię

\footnotetext{
7 Co więcej, praca ta nie może być rozumiana jako prawdziwie odrębny rodzaj ludzkiej pracy, ponieważ w rzeczywistości ta forma pracy stanowi niezbywalny aspekt każdej ludzkiej pracy. Ludzie wytwarzają swoja własną świadomość w trakcie całego życia, nie tylko gdy wykonują dane czynności, takie jak choćby konsumpcja kultury. Z tego też powodu docelowo potrzebna jest ekonomia polityczna świadomości, z tym że jest to potencjalnie niezwykle obszerne pole, które obejmowałoby aspekt produkcji świadomości wszystkich ludzkich czynności i warunki, w których świadomość jest wytwarzana we wszystkich tych przypadkach. Podczas gdy takie rozwinięcie teorii ekonomii politycznej wydaje się konieczne, swój proponowany wkład ograniczam do ekonomii politycznej pracy publiczności w ramach zdefiniowanych ram ekonomii politycznej komunikacji, która wymaga założenia z góry istnienia komunikacji jako czynności postrzeganej oddzielnie, co oznacza założenie istnienia specyficznego kapitału komunikacyjnego.
} 
przyrody” (Marks 1951, 188); „Proces pracy (...) jest (...) przystosowaniem dóbr przyrody” (1951, 195). „Przyroda” w abstrakcyjnym sensie nie istnieje, ale istnieje na poziomie ludzkiej wiedzy o „powszechnym warunku wymiany materii między człowiekiem a przyroda, wiecznym naturalnym warunku życia ludzkiego” (1951, 195). W procesie abstrahowania, niezbędnym do formułowania procesu pracy publiczności w najbardziej ogólnym sensie, również posługuję się kultura jako pojęciem, które zawiera w sobie to, co w rzeczywistości jest nieskończona różnorodnościa.

Proces pracy konkretnej ma za swój przedmiot określoną „materię przyrody”; tak samo jak proces konkretnej pracy publiczności ma za swój przedmiot określoną materię kultury (czy też materiały kultury). Jako przedmiot pracy, kultura nigdy nie jest dostępna „w naturze”; jest zawsze produktem innej pracy ludzkiej, którą nazywam pracą kulturalną. Kultura sama w sobie jest tym, do czego Marks odnosił się jako do „surowca”: przedmiotem pracy „przefiltrowanym przez pracę wcześniejszą” (Marks 1951, 189). Współczesne debaty nad kultura „,remiksu” pokazuja ciagły proces wytwarzania kultury z surowca, jakim jest istniejąca kultura (zob. np. Lessig 2005, 55, 87; Gillespie 2007, 280). Trzeba jednak podkreślić, że przedmiotem pracy publiczności, czyli surowcem kultury, nie jest na przykład książka, ale to, co oznaczone poprzez wizualną reprezentację języka wydrukowaną na stronach, składających się na fizyczną książkę. Surowiec, czyli przedmiot pracy publiczności, jest w swoim najbardziej określonym sensie niematerialny, ale jest zawsze materialny jako część materialnego procesu pracy publiczności: zawsze musi być uprzedmiotowiony i zmaterializowany, ponieważ jest aspektem świadomości pracownika kulturalnego, uprzedmiotowionym w fizycznej formie czy to w mowie, piśmie, czy też języku cyfrowym, który również wymaga fizycznej manifestacji, by mógł być na przykład widziany na ekranie komputera.

Środkiem pracy publiczności jest to, czym praca publiczności posługuje się, by pracować nad przedmiotem tej pracy. „Środkiem pracy jest rzecz lub zespół rzeczy, które robotnik umieszcza między sobą a przedmiotem pracy i które służą mu jako przewodniki jego oddziaływania na ten przedmiot" (Marks 1951, 190). Środkiem pracy publiczności jest medium komunikacyjne, włączając w to elektroniczne i cyfrowe technologie. Mówiąc ogólniej, jest to wszelki środek komunikacji służący do konsumpcji kultury. Środkiem pracy publiczności jest zarówno papier (na przykład książka czy gazeta), jak i telewizja, komputer czy smartphone. Oczy i uszy (jak również inne organy ciała) są najprostszymi środkami pracy publiczności ${ }^{8}$. „Wszelkie przedmiotowe warunki, które są w ogóle potrzebne, żeby proces ten mógł się odbywać”, również są środkami pracy $(1951,191)$.

„Zarówno środki pracy jak przedmiot pracy są środkami produkcji” (Marks 1951, 192). W ramach procesu pracy publiczności do opisu „środków komunikacji, jako środków

8 Tak samo rzecz się ma choćby w przypadku pracy polegającej na zbieraniu owoców: ,za narzędzie pracy służą mu tylko organy jego własnego ciała” (Marks 1951, 190). 
produkcji” (Williams) należy dodać, że kultura stanowi środki produkcji, będąc przedmiotem pracy publiczności. Takie sformułowanie tego problemu pozwala na włączenie pracy publiczności i jej środków produkcji w podstawowy model produkcji wartości dodatkowej z pierwszej księgi Kapitału: kapitalista kupuje siłę roboczą i środki produkcji, zatrudnia je do procesu produkcji wytwarzającego towary mające więcej wartości niż to miało miejsce na początku i wreszcie może zrealizować tę wartość dodatkową w postaci zysku, sprzedając wyprodukowane towary. Jednak proces pracy publiczności i produkcja komunikacyjna, która pojawia się wraz z tym procesem pracy, nie pasują do tego modelu. $Z$ tego też powodu siła robocza publiczności nie może zostać utowarowiona, tak jak dzieje się to z siłą roboczą w modelu produkcji wartości dodatkowej. Wracając do Zarysu krytyki ekonomii politycznej, zauważyć można, że praca publiczności jako akt konsumpcji jest „pojedynczością”. Staje się to jaśniejsze wraz ze zrozumieniem, że produkt pracy publiczności w najbardziej fundamentalnym i abstrakcyjnym sensie jest indywidualną świadomościa.

Proces pracy opisany przez Marksa jest również procesem konsumpcji, różniącym się jednak od konsumpcji indywidualnej:

\begin{abstract}
Praca zużywa swe elementy materialne, swój przedmiot i swe środki, zjada je, a więc jest procesem spożycia. To spożycie produkcyjne tym się różni od spożycia indywidualnego, że ostatnie spożywa produkty jako środki utrzymania żyjącego osobnika, pierwsze zaś - jako środki utrzymania pracy, czynnej siły roboczej osobnika. Produktem spożycia indywidualnego jest przeto sam spożywca, wynikiem zaś spożycia produkcyjnego jest produkt różny od spożywcy (Marks 1951, 194-195).
\end{abstract}

Produktywna konsumpcja jest konsumpcją przedmiotów i środków pracy do wytworzenia produktu, który jest podatny na alienację od swojego producenta, a który z konieczności jest również konsumentem w ramach procesu pracy. Konsumpcja indywidualna jest konsumpcja produktów w celu wyprodukowania konsumenta (dla przykładu, indywidualna konsumpcja jedzenia jako środek utrzymywania się przy życiu), który wskutek tego jest również producentem samego czy samej siebie (Marks 1986, 46). Marks odnosił się do tego również jako „konsumpcji produkcyjnej”. Proces pracy publiczności jest procesem indywidualnej konsumpcji, jako że jest to konsumpcja kultury w postaci konsumpcji środków podtrzymywania społecznej podmiotowości jednostek.

Ostatecznie jednak przemysł kulturalny w samych tylko Stanach Zjednoczonych generuje miliardy zysku z kontroli dostępu do kultury i z pozornego „sprzedawania publiczności” reklamodawcom, co sugerowałoby, że praca publiczności jest w pewien sposób wyzyskiwana i włączona w proces akumulacji kapitału przez przemysł kulturalny. Dotychczasowa ekonomia polityczna utowarowionej publiczności nie wyjaśnia jednak tego procesu, w dużej mierze z powodu jej niewystarczającego teoretycznego skupienia na procesie 
pracy publiczności. Siła robocza publiczności nie jest utowarowiona, a zatem oczywista jest konieczność wykroczenia poza model wytwarzania wartości dodatkowej przez utowarowienie siły roboczej i produktywnej konsumpcji procesu pracy, w celu zrozumienia, w jaki sposób wartość pracy publiczności jest przywłaszczana. Ekonomia polityczna pracy publiczności musi zostać rozwinięta, by móc wyjaśnić stosunek łączący pracę publiczności z akumulacją kapitału i wyzyskiem pracy publiczności. Projekt takiej właśnie ekonomii politycznej zarysuję w kolejnej części.

\section{Wkład w ekonomię polityczną pracy publiczności}

Na gruncie ponownej konceptualizacji procesu pracy publiczności podjętego w poprzedniej części możliwe jest rozwinięcie ogólnego zarysu ekonomii politycznej pracy publiczności jako teorii wewnątrz ekonomii politycznej komunikacji. Wymaga to zarówno posłużenia się Marksowską metodą ekonomii politycznej, jak i nawiązania do Williamsa w celu ujęcia komunikacji jako produkcji komunikacyjnej, czynności komunikacyjnych zaś jako pracy. Oznacza to również ograniczenie przedmiotu rozważań do pracy publiczności w ramach produkcji komunikacyjnej w celu spojrzenia na proces oznaczania poprzez konsumpcję kultury jako na proces akumulacji kapitału. Takie określenie ekonomii politycznej pracy publiczności jest równoznaczne z postrzeganiem komunikacji jako kapitału.

\subsection{Komunikacja jako kapitał}

Kapitał, który cyrkuluje i akumuluje szczególnie poprzez proces komunikacyjny, nazywam kapitałem komunikacyjnym. Kapitał komunikacyjny nie może utowarowić siły roboczej publiczności i odciąać wartości dodatkowej przez przywłaszczanie produktów pracy publiczności, ponieważ produkty tej pracy w bezpośrednim sensie są niematerialne i podmiotowe. Mowa tu o znaczeniu wytworzonym podczas konsumpcji kultury, a jeśli weźmie się jeszcze pod uwagę ludzką pamięć, produkt ten można rozszerzyć na znaczenie wytwarzane już po czynnościach konsumpcji. Kapitał komunikacyjny może kontrolować proces pracy publiczności w postaci oznaczania tylko poprzez konsumpcję kultury i wyciąać wartość z tego procesu przez kontrolę przedmiotów tej konsumpcji. Ekonomia polityczna pracy publiczności pokazuje, że akumulacja kapitału komunikacyjnego jest procesem przywłaszczania wartości w jego podziale. Na poziomie „ogólności” wytwarzana jest wartość dodatkowa; na poziomie „szczególności” wartość dodatkowa jest dzielona (Harvey 2006, 61, 69).

Poniżej będę uzasadniać, że komunikacyjni kapitaliści w gruncie rzeczy starają się redystrybuować wartość z płac pracowników jako formę odprowadzania renty, jak również otrzymywać udział z podziału wartości dodatkowej od innych kapitalistów przez reklamy rozumiane jako forma płacenia procentu. $\mathrm{Z}$ tego powodu przy konstruowaniu ekonomii 
politycznej pracy publiczności konieczne jest włączenie „szczególności” dystrybucji w „ogólność” produkcji. Jako że praca, o której tu mowa, jest praca publiczności w postaci indywidualnej konsumpcji kultury, nieodzowne jest również włączenie „pojedynczości” konsumpcji w „ogólność” produkcji. Mam na myśli włączanie w produkcję, ponieważ ekonomia polityczna jest teorią opisującą poziom „ogólności” czyli produkcji, a zatem potrzebna staje się bardziej historyczna perspektywa, pozwalająca na stworzenie pełniejszej wiedzy o „szczególności” dystrybucji i, zwłaszcza, o „pojedynczości” konsumpcji. Ekonomia polityczna może się zajmować tylko tymi aspektami, które odnoszą się do „ogólności” produkcji. Jako że artykuł ten jest próbą wniesienia wkładu w rozwój ekonomii politycznej pracy publiczności w ramach kapitalistycznego sposobu produkcji komunikacyjnej, zajmę się dystrybucją i konsumpcją w tym wymiarze, w jakim odnoszą się one do akumulacji kapitału poprzez produkcję komunikacyjna.

Podczas gdy reklamy oferują jeden z potencjalnych punktów wyjścia badania stosunku pomiędzy praca publiczności a akumulacją kapitału, jako że wydaje się to sytuacją, w której kapitał komunikacyjny „sprzedaje publiczność” reklamodawcom, stosunek pomiędzy kapitałem komunikacyjnym, praca publiczności a reklamodawcami pokazuje właściwie konieczność odsłonięcia bardziej fundamentalnego stosunku: stosunku społecznego, który najpierw wytwarza pracowników publiczności, a który jest społecznym stosunkiem pomiędzy kapitałem komunikacyjnym a pracą publiczności. Wizja kapitału komunikacyjnego sprzedającego publiczność skłoniła Smythe’ego do sformułowania koncepcji pracy publiczności jako towaru, a Jhally'ego i Livanta do steoretyzowania konkretnej pracy publiczności (czasu) jako towaru. Jeśli jednak kapitał komunikacyjny ma zarówno zdolność sprzedawania siły roboczej publiczności, czasu pracy czy czegoś jeszcze niezdefiniowanego i odnoszącego się do czynności publiczności, a także posiada zdolność kierowania procesem pracy publiczności do pracy nad reklamami, tak, aby w ten sposób akumulować kapitał przez wpływy z reklam, to istnieje zatem pewien stosunek społeczny, w którym kapitał komunikacyjny ma ten rodzaj władzy nad praca publiczności. To właśnie ten stosunek definiuje pracę publiczności jako szczególny rodzaj pracy, która w określony sposób odnosi się do kapitału. Zdefiniowanie tego stosunku umożliwia zrozumienie stosunku pomiędzy praca publiczności, kapitałem komunikacyjnym i reklamodawcami, w którym kapitał komunikacyjny używa swojej władzy nad praca publiczności do przywłaszczenia wartości nie bezpośrednio z pracy publiczności, ale raczej od reklamodawców.

\subsection{Połączenie krytyk Smythe'ego: oddzielenie wyzysku pracy publiczności od utowarowionej publiczności}

Jak pokazali Chih-hsien Chen (2003) i Brett Caraway (2011), zasadniczy błąd ekonomii politycznej utowarowionej publiczności Smythe’ego leżał w koncepcji utowarowionej siły 
roboczej publiczności. Rozwijanie zatem koncepcji Smythe’ego, jak robi to znaczna część ekonomii politycznej pracy cyfrowej, tylko potęguje ten błąd. A jednak w swoich krytykach zarówno Chan, jak i Caraway umieszczaja pracę publiczności jeszcze dalej poza obrębem perspektywy ekonomii politycznej. Moim celem jest położenie akcentu wprost na pracy publiczności. Chen i Caraway przedstawiają koncepcję renty i kapitału fikcyjnego jako narzędzi niezbędnych dla wytłumaczenia akumulacji kapitału w stosunku do (cyfrowej) komunikacji. Zgadzam się, że pojęcia te są nieodzowne dla ekonomii politycznej pracy publiczności, tłumaczącej proces akumulacji kapitału przez wyzysk pracy publiczności. Również Matteo Pasquinelli (2009; 2010) argumentował za kluczowym znaczeniem pojęcia renty. Z kolei Christian Fuchs jednoznacznie odrzucił próby stosowania pojęcia renty do wyjaśniania procesu akumulacji kapitału przez wyzysk pracy cyfrowej. Uważał bowiem, że „posługiwanie się kategoria renty do opisania praktyk związanych z mediami komercyjnymi i Internetem oraz ich efektami oznacza założenie, że czynności odnoszące się do mediów komercyjnych i Internetu (...) nie sa wyzyskiwane i nie sa rodzajem pracy" (Fuchs 2012, 732).

Jhally i Livant (1986) pierwsi zasugerowali, że renta jest użyteczna kategoria w ekonomii politycznej utowarowionej publiczności, ale nie dążyli do włączenia stosunku podziału definiowanego przez rentę we własny projekt teoretyczny. Również Chen (2003) podąża za Jhallym i Livantem, umieszczając utowarowiona publiczność w obszarze cyrkulacji. Sugeruje to, że stosunek pracy publiczności do kapitału jest produkcyjny, ponieważ przyspiesza stopę obrotów i realizację wartości dodatkowej z reklamowanych towarów. Chen nie zajmuje się jednak fundamentalnym stosunkiem pomiędzy pracą publiczności a kapitałem komunikacyjnym. W jego teorii kapitaliści produkcyjni, jako reklamodawcy, w zamian za dostęp do publiczności, płacą rentę kapitalistom komunikacyjnym (Chen 2003, 9-10). W ten sposób kapitał komunikacyjny przywłaszcza sobie część wartości dodatkowej kapitału produkcyjnego, a kapitał produkcyjny płaci ja, „by zapobiec kryzysowi realizacji” (2003, 11). Podsumowując, Chen stwierdza, że utowarowiona publiczność konstytuuje fikcyjny towar i tym samym przyznaje racje poglądowi Meehan, że utowarowiona publiczność to w rzeczywistości tylko utowarowione wskaźniki - „skonstruowany obraz publiczności” (Chen 2003, 13). Komunikacyjny kapitał zatem wytwarza i wprowadza w obrót kapitał fikcyjny, ponieważ w rzeczywistości nie kupuje (ja uznaję, że nie jest w stanie) siły roboczej publiczności. Wartość fikcyjnej utowarowionej publiczności konstytuowana jest przez kredyt wygenerowany przez utowarowione wskaźniki (2003, 13). Kredyt ten ujmowany jest przez Chena jako renta: fikcyjna utowarowiona publiczność kapitału komunikacyjnego jest kupowana przez reklamodawców/kapitalistów produkcyjnych - za pomocą zapłaconych pieniędzy konstytuuje kapitał fikcyjny w postaci kredytu, gdyż wymiana jest procesem spekulacji ze strony kapitału produkcyjnego, możliwej dzięki przyjęciu, że zakup (fikcyjnej) utowarowionej publiczności wytworzy więcej wartości dodatkowej przez szybszą realizację (2003, 12-13). W związku z tym 
Chen twierdzi, że kapitał komunikacyjny w rzeczywistości akumuluje dług poprzez pieniądze pochodzące z reklam, które otrzymał w postaci kredytu od kapitalistów produkcyjnych. Twierdzenie to zdaje się jednak negować samo siebie. Chen twierdzi również, że „akumulacja długu może jawić się jako akumulacja kapitału tak długo, jak publiczność/konsumenci/robotnicy poważnie nie zakwestionują cyrkulacji fikcyjnej utowarowionej publiczności” (2003, 15).

Podczas gdy Chen stworzył użyteczną perspektywę, wykorzystując pojęcie kapitału fikcyjnego w rozumieniu stosunku zawiązywanego pomiędzy kapitalistami komunikacyjnymi a reklamodawcami - perspektywę, którą omówię jeszcze w dalszej części, posługując się rozwinięciem tego pojęcia przez Harveya w stosunku do kapitalizacji renty (Harvey 2006) jego przedstawienie „opartej na kredycie ekonomii telewizji” nie wytrzymuje krytyki. Chen twierdzi, że rzeczywiście wykonywana praca publiczności nie istnieje (Chen 2003, 14), a zatem nie poświęca uwagi również procesowi pracy publiczności. Z kolei ja utrzymuję, że praca publiczności znajduje się w samym sercu akumulacji kapitału poprzez konsumpcję kultury. Towar wymieniany pomiędzy kapitałem komunikacyjnym a reklamodawcami wcale nie jest fikcyjny - jest nim kultura w postaci przedmiotu pracy publiczności. W rzeczywistości jest to dostęp do kultury, kontrolowany przez kapitał komunikacyjny za pomoca prawa autorskiego i innych środków. Wrócę jeszcze do tego po rozważeniu, jaki wkład wnosi inna krytyka ekonomii politycznej utowarowionej publiczności do opracowania władzy kapitału komunikacyjnego nad pracą publiczności.

Caraway (2011) wychodzi od poglądu Chena, że pojęcie renty i fikcyjnego kapitału dostarcza środków do naprawienia błędów dotychczasowej ekonomii politycznej utowarowionej publiczności $(2011,701)$. Wskazuje przy tym na centralna rolę renty w wymianie tego, co Smythe i inni nazwali utowarowioną publicznościa, ale jednocześnie fakt ten staje się dla niego dowodem na to, że nie ma żadnej „pracy publiczności”, a wobec tego z pewnościa nie mamy do czynienia z zachodzeniem jakiejkolwiek postaci wyzysku pracy publiczności. Caraway zakłada aprioryczna potrzebę ,zrównoważonego podejścia do analizy klasowej pracy darmowej” (2011, 694), to znaczy pracy cyfrowej, ponieważ zakłada, zgodnie z ogólną perspektywą marksizmu autonomistycznego, immanentny proces emancypacji ludzkiej pracy w połączeniu ze zwiększającym się znaczeniem ,wiedzy i społecznej kooperacji w organizacji pracy” (2011, 693), to znaczy większego znaczenia „pracy niematerialnej”, „intelektu powszechnego” i „fabryki społecznej”. Twierdzi, że ekonomia polityczna utowarowionej publiczności „ma tendencję do przypisywania zbyt dużej wagi urzeczywistnianiu” wysiłków kapitału w wyzysku pracy cyfrowej, który zawsze jest „przygodny, sprzeczny i zakwestionowany” (2011, 694). Podczas gdy zgadzam się z tą drugą teza, „zrównoważone podejście”, tak jak posługuje się nim Caraway, prowadzi do wniosku, że „,antagonizm klasowy” napędza „trajektorię rozwoju kapitalistycznego" w produkcji komunikacyjnej, prowadząc 
w konsekwencji do emancypacji pracy komunikacyjnej (2011, 706). Dla Carawaya teoria wyzysku pracy publiczności Smythe’ego jest ze swej natury „kontrrewolucyjna” (2011, 702), właśnie ze względu na twierdzenie, że taki wyzysk istnieje.

Wbrew temu, co twierdzi Caraway, teoria Smythe’ego nie odrzuca „podmiotowości publiczności” (Caraway 2011, 705). Podkreślał on bowiem, że podmiotowość publiczności jest zaprzęgnięta do pracy w postaci produkcji ideologii. Carraway opisał również podmiotowość publiczności jako „podmiotowość klasy robotniczej”, co jasno pokazuje - jednocześnie stanowiąc prawdę w odniesieniu do krytykowanej przez niego ekonomii politycznej utowarowionej publiczności - że rozważał raczej utowarowioną publiczność i pracę publiczności z perspektywy cyrkulacji i akumulacji kapitału w ogóle, a nie w ramach komunikacji. Z tego też powodu Caraway przedstawia jako argument podważający teorię Smythe'ego twierdzenie, że robotnicy walczyli właśnie o ten czas wolny, który, według Smythe'ego, został zmieniony w czas pracy publiczności (Caraway 2011, 702-704). Sama debata nad czasem wolnym nie mieści się w obszarze dyskusji nad tym, czy praca publiczności jest wyzyskiwana, co samo z siebie z konieczności musiałoby być procesem zachodzącym w ramach produkcji komunikacyjnej. Smythe niestety nie przyjrzał się uważniej procesowi pracy publiczności. Gdyby to uczynił, dostrzegłby, że członkowie publiczności nie pracuja tylko podczas konsumowania reklam (gdy wytwarzają ideologię konsumpcji, która stwarza popyt na towary), ale, mówiąc precyzyjniej, pracują zawsze, gdy tylko konsumują kulturę, a więc zawsze, gdy są w pozycji członków publiczności i konsumentów kultury w stosunku do kapitału komunikacyjnego. Również Caraway nie przyjrzał się temu procesowi z należyta uwaga z perspektywy teorii ekonomii politycznej. Ze szczególnej perspektywy pracy publiczności i pojmowania procesu pracy publiczności jako oznaczania poprzez konsumpcję kultury, jasnym staje się, że opór ze strony pracy publiczności nie przeszkadza kapitalistycznej akumulacji.

Caraway $(2011,697)$ wskazuje jednak na fundamentalny błąd ekonomii politycznej Smythe'ego, zawierający się w teorii utowarowienia siły roboczej publiczności. Jak zauważył (i jak już zwróciłem na to uwage powyżej), „publiczność nie jawi się jako sprzedawca towarów w rozumieniu Smythe'ego” (Caraway 2011, 697), tak jak robotnik w Marksowskim rozumieniu siły roboczej jako towaru z pierwszej księgi Kapitału. Caraway odwołuje się następnie do modelu Marksa, by pokazać, że teoria Smythe'ego jest mylna, przekonując przy tym, że wyzysk pracy jest możliwy tylko w procesie, który pasuje do tego modelu. Ponadto Caraway twierdzi, że teoria Smythe'ego jest w rzeczywistości teorią renty i co za tym idzie, nie może być teorią wyzysku pracy. Co więcej, Caraway uważa, że właśnie renta jest właściwym sposobem teoretyzowania stosunku pomiędzy tym, co nazywam kapitałem komunikacyjnym, a reklamodawcami $(2011,701)$. Moim zdaniem podstawowe sformułowanie problemu przez Carawaya jest prawidłowe, jeśli tylko słowo „wynajmuje (rents)” zastapi się słowem 
„wypożycza (lends)”: „Właściciel medium wynajmuje użytek z tego medium kapitaliście produkcyjnemu, który jest zainteresowany uzyskaniem dostępu do publiczności. Wynajem może dotyczyć czasu (...) albo przestrzeni” (2011, 701). Tak formułując problem, Caraway intencjonalnie wyeliminował pracę publiczności z teorii. Uważam, że pojęcie renty w rzeczywistości pomaga wyjaśnić proces wyzysku pracy publiczności.

Caraway ma również rację twierdząc, że Smythe nie zaproponował „wyjaśnienia” faktu, że proces pracy publiczności „znajduje się pod kontrolą kapitalisty; jak również nie próbował pokazać, że wartość użytkowa jest wyalienowana od publiczności” (2011, 697). Jak dowodzę powyżej, żadnego z tych ujęć nie da się przedstawić bez głębszego rozważenia samego procesu pracy publiczności. Pomimo tego, że Caraway nie zdecydował się pójść w kierunku takiej interpretacji i mimo ciagłego nacisku na „podmiotowość publiczności” w momencie, w którym podkreślał to, co postrzegał jako pominięcie tej subiektywności przez Smythe'ego, podsumował, że członkowie publiczności nie „pracuja dla kapitału, gdy interpretują teksty medialne” (2011, 701). Innymi słowy, jego zdaniem nie wykonuja pracy publiczności, którą opisałem jako oznaczanie przez konsumpcję kultury, ponieważ, jak pisze, „znaczenia”, postrzegane przez niego jako „wartości użytkowe” uzyskane w toku tej interpretacji, nie znajdują się „pod wystarczającą kontrolą kapitalisty” (2011, 701). W rzeczywistości jednak prawo autorskie jest dokładnie tym stosunkiem własności, który podporządkowuje interpretacje tekstów medialnych kontroli kapitału w postaci pracy publiczności, która może zostać poddana wyzyskowi, jak i stosunkiem dystrybucji będącym „dystrybucją opartą na produkcji” (Harvey 2006, 332), dzięki któremu kapitał ma władzę nad produkcja komunikacyjna, która wystarcza, aby przywłaszczać wartość i akumulować kapitał w stosunku do tego procesu produkcji. Rozwinę ten punkt poniżej.

\subsection{Akumulacja kapitału poprzez wyzysk pracy publiczności}

Wychodząc od intuicji Chena i Carawaya, należy rozwinąć teorię stosunku społecznego, definiującego pracę publiczności wewnątrz kapitalistycznego sposobu produkcji komunikacyjnej: stosunku pomiędzy praca publiczności a kapitałem komunikacyjnym. Praca publiczności, jako indywidualna konsumpcja i proces indywidualnego oznaczania, jest „pojedynczością”. Z tego powodu siła robocza publiczności nie może zostać utowarowiona, bowiem jej produkt, czyli znaczenie, nigdy nie może zostać wyalienowany, tak jak dzieje się to w przypadku innych wytworów ludzkiej pracy (nie chodzi więc o kontrolę umysłu). Produkt ten w swojej podstawowej formie jest niematerialny, ale może i zawsze musi zostać zmaterializowany, nie tylko po to, by zostać „zakomunikowany”, ale również, żeby stać się „praktyczną świadomością” żyjącej osoby, czy to w postaci działania kierowanego myślami, mówionym językiem wyrażającym myśli, czy też przedmiotami kulturalnymi wyrażającymi myśli w języku, obrazach itd. Posiadanie zdolności innej osoby do oznaczania nie jest możliwe 
tak, jak możliwe jest utowarowienie siły roboczej jako ogólnej ludzkiej możliwości do wytwarzania - przez świadome czynności - produkcji materialnej. Nie oznacza to jednak, że praca publiczności jest wolna od społecznego określania czy nawet wyzysku. Możliwym jest bowiem posiadanie środków produkcji komunikacyjnej, które są środkami konsumpcji kultury przez pracę publiczności: zarówno kultura jako przedmiot pracy publiczności, jak i w niektórych przypadkach media jako środki pracy publiczności, moga być w posiadaniu kapitału. Dzięki posiadaniu środków produkcji komunikacyjnej „,pojedyncza” praca oznaczania wykonywana przez członków publiczności może być włączona w proces cyrkulacji i akumulacji kapitału. To samo tyczy się cyfrowej pracy publiczności i z tego też powodu kluczowe jest, by nie połączyć cyfrowej pracy publiczności i cyfrowej pracy kulturalnej z ekonomia polityczną komunikacji.

„Szczególność” podziału jest również kluczowym aspektem kapitalistycznej produkcji komunikacyjnej. Stosunek społeczny, który najbardziej bezpośrednio definiuje pracę publiczności, jest stosunkiem podziału: renta. Posiadanie przez kapitał przedmiotu pracy publiczności, czyli kultury, stwarza pracę publiczności przez wytworzenie stosunku klasowego pomiędzy tymi, którzy posiadają kulturę, a tymi, którzy jej nie posiadają. Własność ta ujawnia się rzecz jasna w prawie autorskim. Kultura nie jest jednak zwyczajnym towarem. Posiadanie kultury na własność jest warunkowane szczególnymi cechami kultury jako przedmiotu pracy i środków produkcji: kultura jest zasadniczo niematerialna, kiedy ujmujemy ja jako „znaczenia”, „idee” czy „informacje” oznaczone w produktach kultury, tak jak to tu definiuje, a nie jako materialne medium, przez które stają się one dostępne. By kultura mogła być przedmiotem pracy, musi jednak, rzecz jasna, zostać uprzedmiotowiona, a więc zmaterializowana. Kultura jest zatem „niekonkurencyjna”: konsumpcja jej przez jedną osobę nie wyklucza skonsumowania jej przez inną osobę (Benkler 2008, 51). Konsumpcja kultury nie jest zatem tym samym, co konsumpcja towarów podlegających konkurencji. Idee, znaczenia, wyrazy itd., a także zobiektywizowana w nich świadomość, nie są nigdy w pełni konsumowane, ale jedynie używane - jako przedmioty, na których dokonuje się praca publiczności wytwarzająca subiektywne znaczenie - i mogą być powtórnie użyte przez innego pracownika czy nawet tego samego (na przykład podczas ponownego czytania książki). Tak długo, jak kultura istnieje w uprzedmiotowionej formie, może być przedmiotem pracy.

Zakup towarów kulturalnych jest zawsze tylko płaceniem za dostęp. Dla kapitału jest to przywłaszczenie wartości dodatkowej, w rezultacie jej podziału, jako renty. Nie zachodzi natomiast wymiana samych praw własności kultury. Dla przykładu, osoba kupująca książkę nie staje się właścicielem świadomości uprzedmiotowionej i zmaterializowanej w samej książce. Zakupiona zostaje jedynie możliwość posiadania fizycznego obiektu w postaci książki, ale właścicielem „idei” wyrażonych w materialnej formie w postaci języka wydrukowanego na papierze pozostaje wciąż posiadacz praw autorskich. Posiadacz praw autorskich jest 
kulturalnym „właścicielem ziemskim”, który nie akumuluje kapitału poprzez sprzedaż towarów, ale raczej przez udzielanie - za opłata - dostępu do prywatnie posiadanych zasobów kultury. Innymi słowy, opłacany jest poprzez rentę.

Dla kapitalistycznej produkcji komunikacyjnej proces konsumpcji - przypominający typową konsumpcję towarów, a co za tym idzie, zakończenie procesu akumulacji kapitału w postaci realizacji wartości dodatkowej przez zakup towaru, który jest następnie konsumowany - pełni centralną rolę dla procesu produkcji dla akumulacji kapitału. Nawet w handlu książkami, który wydaje się historycznym początkiem kapitalistycznego sposobu komunikacyjnej produkcji, raczej praca publiczności, a nie praca kulturalna uprzedmiotawiania idei w fizycznej postaci książki, była kluczowym procesem pracy, dzięki któremu proces komunikacji stawał się procesem akumulacji kapitału. Posiadanie na własność kultury jako przedmiotu i surowca pracy publiczności jest podstawą samej pracy publiczności - jest społecznym stosunkiem (jak i stosunkiem własności), przez który jednostki stają się konsumentami kultury i których czynności sa źródłem wartości dla komunikacyjnego kapitału z powodu jego kontroli nad środkami produkcji. Pod tym względem kultura jest jak ziemia i użycie jej jako środków produkcji w produkcji komunikacyjnej tworzy proces wyzysku - który tak, jak w przypadku ziemi, pojawia się na poziomie dystrybucji - przez przywłaszczenie wartości (dodatkowej) w postaci renty.

„Siła monopolu” sprawowanego poprzez „własność prywatna ziemi jest podstawa renty jako formy ekstrakcji wartości dodatkowej" (Harvey 2006, 73). To samo można powiedzieć o kulturze. Harvey dodaje jeszcze kluczowy argument głoszący, że siła prywatnej własności ziemi „byłaby niczym (...) gdyby nie fakt, że ziemia jest niezbędnym warunkiem produkcji w ogóle (...), nawet środków produkcji” (2006, 73). To samo odnosi się do kultury: to właśnie dlatego, że kultura jest warunkiem i środkami produkcji komunikacyjnej zachodzącej poprzez społeczne oznaczanie, własność prywatna kultury w postaci praw autorskich stwarza siłę monopolu dla posiadacza praw autorskich, która może być użyta do przywłaszczenia renty. Przywłaszczenie renty jest stosunkiem podziału, który oddziałuje również na „warunki produkcji” (Harvey 2006, 69).

$\mathrm{Na}$ produkcję komunikacyjną oznaczania przez publiczność renta oddziałuje jako warunek występowania tej produkcji: dostęp do kultury jest niezbędny dla produkcji komunikacyjnej przez proces pracy publiczności, ale posiadacz praw autorskich kontroluje ten dostęp. Stosunki dystrybucji są również stosunkami klasowymi: nie ma czegoś takiego jak po prostu „kapitał”, sa różni kapitaliści, którzy w różny sposób przywłaszczaja sobie wartość dodatkową (w postaci zysków z produktywnego kapitału, zysków z handlowego kapitału, procentu z pieniężnego kapitału czy renty), dlatego też istnieja „frakcje” czy klasy: kapitaliści produkcyjni, kapitaliści handlowi, rentierzy i właściciele ziemscy (Harvey 2006, 73-74). Posiadacz praw autorskich jest zatem niczym właściciel ziemski, ale jest również pewnym 
rodzajem kapitalisty. Właściciel ziemski w kapitalistycznym sposobie produkcji nie używa ziemi, ale zamiast tego traktuje prywatnie posiadaną ziemię jako czysty zasób finansowy (Harvey 2006, 347): „w zamian za bezpośrednią zapłatę pieniężną” właściciel ziemski „przyznaje wszystkie prawa do ziemi jako narzędzie i warunek produkcji” (2006, 343). Właściciel kultury działa podobnie, dając prawa do użycia kultury w zamian za zapłatę, a co za tym idzie, przywłaszczając sobie albo wartość z płacy pracownika najemnego, albo wartość dodatkowa z zysku, odsetek czy renty innego kapitalisty. Każda jednostka, która chce uzyskać dostęp do kultury posiadanej przez komunikacyjnego kapitalistę, staje się pracownikiem publiczności, a wykonywane przez tę jednostkę czynności oznaczania przez konsumpcję kultury stają się środkami, przez które komunikacja jest traktowana jako kapitał. Konsumpcja kultury staje się zatem czynnością wyzyskiwaną.

Harvey (2002, 98) twierdzi, że szczególny rodzaj renty, który może być przywłaszczony za pomoca praw autorskich, jest renta monopolowa. „Wszelka renta jest ugruntowana na sile monopolu prywatnych właścicieli (...) na mocy ich wyłącznej kontroli nad pewną bezpośrednio lub pośrednio wymienialną rzeczą, która w niektórych kluczowych przypadkach jest unikatowa i niedająca się powielić" $(2002,94)$. Cytat ten z pewnością zdaje się opisywać kulturę jako posiadany na własność zasób. Tam, gdzie nie ma konkurencji o własność prywatnie posiadanych zasobów, realizowana może być renta monopolowa (Harvey 2006, 350) i tak z pewnością ma się sprawa z prawem autorskim, które z definicji jest prawem monopolowym, a nie prawem własności poddanym konkurencji.

Środki pracy publiczności, tak jak środki produkcji komunikacyjnej, również istniały w formie własności posiadanej przez komunikacyjny kapitał, tak jak w przypadku ekranu w kinie (czy też samego teatru). Pracownicy publiczności na ogół posiadajajednak podstawowe środki własnej pracy w postaci kupionych przez siebie towarów - książki, gazety, radia, telewizji czy komputera. Kwestia własności środków pracy publiczności nie jest zatem istotna dla ogólnego stosunku pomiędzy kapitałem komunikacyjnym a praca publiczności, chociaż jest to definiujący aspekt dla szczególnych procesów pracy publiczności, takich choćby, jak oglądanie filmów w kinie. Fundującym stosunkiem i stosunkiem, dzięki któremu definiowany jest kapitalistyczny sposób produkcji komunikacyjnej, jest natomiast stosunek „dystrybucji determinującej produkcje" stworzony przez własność prywatną kultury. Ten społeczny stosunek podziału warunkuje proces produkcji komunikacyjnej oznaczania przez publiczność.

Praca publiczności jest wyzyskiwana przez kapitał komunikacyjny w ramach stosunku podziału, który warunkuje proces produkcji; praca publiczności opiera się więc na kapitale komunikacyjnym w kwestii dostępu do przedmiotu i „surowca”, których potrzebuje jako środków oznaczania dokonywanego poprzez konsumpcję kultury. Kapitał komunikacyjny może użyć swojej władzy nad praca publiczności do przywłaszczenia wartości bezpośrednio z pracy publiczności przez, na przykład, pobieranie opłaty za dostęp do monopolistycznie 
posiadanej kultury. To odciagnięcie renty jest procesem bezpośredniego wyzysku pracy publiczności przez kapitał komunikacyjny, gdyż wartość jest przywłaszczana bezpośrednio z pracy publiczności.

Kapitał komunikacyjny może również użyć swojej władzy nad praca publiczności do przywłaszczenia wartości dodatkowej od reklamodawców, dostarczając jednocześnie pracy publiczności darmowy dostęp do kultury. Reklamodawcy mogą osiagnąć wyłącznie swój bezpośredni cel, czyli wpłynąć na rzeczywiste znaczenie wytwarzane w procesie oznaczania przez publiczność, zmieniając przedmiot konsumpcji kultury w oznaczone przedmioty stworzone do wywoływania szczególnego „efektu”, kiedy są konsumowane i kiedy się nad nimi pracuje w procesie oznaczania przez pracę publiczności. Reklamodawcy nie posiadaja jednak przedmiotów pracy publiczności. Posiadają je komunikacyjni kapitaliści. Jeśli posiadanie kultury dostarcza właścicielowi siłę do przywłaszczania ciagłego strumienia renty (do momentu wygaśnięcia praw autorskich), renta ta może być traktowana jako kapitał przez jej kapitalizację w postaci „odsetek z jakiegoś wyimaginowanego, fikcyjnego kapitału” (Harvey 2006, 347). Tak rzecz się ma z kapitałem komunikacyjnym wypożyczającym kulturę reklamodawcom, który nie daje w tym wypadku dostępu do użytku, tak jak ma to miejsce w momencie, w którym renta jest przywłaszczana z pracy publiczności, ale raczej udziela pożyczki części uprzedmiotowionej formy samej kultury, tak jak ma to miejsce choćby w przypadku wypożyczania przestrzeni w gazecie, przez co część tej przestrzeni staje się miejscem reklamowym, czy też w sytuacji wypożyczania czasu programu telewizyjnego, w rezultacie czego część tego czasu staje się czasem reklamowym. W zamian za pożyczkę przestrzeni czy czasu kultury w postaci fikcyjnego kapitału, reklamodawcy płaca procent wypożyczającym, komunikacyjnym kapitalistom.

Odprowadzenie procentu z reklam to raczej pośrednia forma wyzysku pracy publiczności przez kapitał komunikacyjny. Ostatecznie bowiem wartość dodatkowa jest w tym wypadku odprowadzana raczej od reklamodawcy niż od pracownika publiczności. Uważam, że proces ten w dalszym ciągu może być postrzegany jako ten, w którym praca publiczności jest pośrednio wyzyskiwana, ponieważ kapitał komunikacyjny używa swojej kontroli nad czynnościami publiczności konsumpcji kultury by przywłaszczyć sobie wartość i w procesie tym bezpośrednio modyfikuje proces pracy publiczności przez przekształcenie części przedmiotu tego procesu pracy w reklamę. Reklamodawca, dzięki odprowadzeniu procentu, zyskuje część władzy komunikacyjnego kapitału nad pracą publiczności. Jako właściciel kultury i, co za tym idzie, posiadacz części władzy nad czynnościami publiczności (ale nigdy wystarczającej do zmuszenia pracy publiczności do sprzedania swojej siły roboczej), kapitalista komunikacyjny ma pozycję dominująca wobec reklamodawcy, szukającego sposobów zdobycia siły pozwalającej wpływać na proces pracy publiczności. Jednak od momentu, w którym kapitał komunikacyjny staje się zależny od procentu przywłaszczanego od 
reklamodawców jako jedynego źródła wartości dodatkowej, to kapitał komunikacyjny zajmuje podporządkowana pozycję w stosunku do reklamodawców.

Gdy kultura wymieniana jest jak towar, pożyczana przez kapitał komunikacyjny reklamodawcom, proces ten staje się nie tyle po prostu przywłaszczeniem procentu, ile cyrkulacją kapitału fikcyjnego. Wydaje się, że w tym przypadku wyraźnie widać różnicę między kultura a ziemia. Renta z ziemi może być kapitalizowana w postaci kapitału fikcyjnego przez sprzedaż „tytułu do (...) własności renty. Wydane pieniądze stanowią ekwiwalent dla procentującej inwestycji. Kupujący zyskuje prawo do przyszłych oczekiwanych wpływów, prawo do przyszłych owoców pracy" (Harvey 2006, 367). Wydaje się natomiast, że reklamodawcy, jako wypożyczający kulturę, nie starają się uzyskać własności prawa do renty, która może być przywłaszczona w przyszłości dzięki kontroli nad szczególnym przedmiotem kultury. Nie poszukują też sposobów przywłaszczania wartości dodatkowej z pracy publiczności w procesie komunikacyjnej produkcji oznaczania przez konsumpcję kultury. Reklamodawcy szukaja jedynie praw do przyszłych owoców pracy, w tym przypadku szczególnych owoców czy produktów pracy publiczności: znaczenia.

Tym samym powraca kwestia „pojedynczości” i fakt, że produktem pracy publiczności, w najbardziej ogólnym sensie, jest świadomość. Reklamodawcy są zainteresowani tym właśnie produktem. Jeśli nadrzędnym celem reklamy jest ułatwienie sprzedaży towaru, to nie jest to proces zachodzacy $w$ ramach komunikacji jako kapitału i nie dotyczy on bezpośrednio pracy publiczności. Jedynym sposobem na ułatwienie sprzedaży towarów w ramach komunikacji jest oddziaływanie na rzeczywistą świadomość wytwarzaną przez konkretne jednostki, a więc to, co Smythe opisał jako produkowanie ideologii konsumenckiej świadomości, która stwarza popyt na reklamowane towary. Jeśli kapitał komunikacyjny poszukuje sposobów na przywłaszczenie wartości przez posiadanie przedmiotu pracy publiczności (czy to bezpośrednio dzięki opłacie wniesionej przez pracę publiczności, czy też pośrednio przez wpływy z reklam) i jest wyłącznie zainteresowany szczególną świadomością produkowana przez oznaczanie pracowników publiczności w ten sposób, że na przykład popularność wiąże się z relatywnie większą rentą czy procentem, to reklamodawcy są zainteresowani szczególną świadomością, która „wywrze” wpływ na konkretne jednostki przez uczynienie reklam przedmiotami pracy publiczności tych jednostek. Wydaje się zatem, że Smythe miał racje przynajmniej co do jednej rzeczy: dla reklamodawców praca publiczności jest wtedy produkcyjna, gdy wytwarza szczególną świadomość konsumencką, stwarzająca popyt na towary. 


\section{Wnioski}

Zarysowana powyżej ekonomia polityczna pracy publiczności opisuje podstawowy proces, poprzez który praca publiczności jest wyzyskiwana i włączana w mechanizm akumulacji kapitału komunikacyjnego. Pokazuje też produktywność specyficznego skupienia się na pracy publiczności dla studiów w dziedzinie ekonomii politycznej komunikacji, sprawiając, że może ona zacząć ujmować teoretycznie jeden z fundamentalnych aspektów komunikacji jako kapitału w erze cyfrowej: wyzysk cyfrowej pracy publiczności. Mimo że pojęcie pracy publiczności zostało początkowo sformułowane w odniesieniu do ekonomii politycznej komunikacji w erze drukowanych i elektronicznych mediów masowych, pozostaje niezbędnym pojęciem również dla ekonomii politycznej cyfrowej komunikacji. Każda firma funkcjonująca w roli kapitalisty komunikacyjnego poprzez wytwarzanie zysku pochodzącego z opłat za dostęp do kultury czy zysku z reklam w rzeczywistości wyzyskuje pracę publiczności. Odnosi się to do większości firm związanych z cyfrową komunikacją. Wydaje się, że kontrolowanie i wyciaganie wartości z czynności publiczności - które, trzeba dodać, są czynnościami konsumpcji kulturowej - jest główną forma (ale oczywiście nie jedyna) ujmowania komunikacji epoki cyfrowej jako kapitału.

Dotychczasowy rozwój ekonomii politycznej pracy cyfrowej zaowocował wieloma spojrzeniami na kapitalistyczny sposób cyfrowej produkcji komunikacyjnej; nie udało się jednak ując we właściwy sposób centralnej roli cyfrowej pracy publiczności. Artykuł ten ma zainicjować proces wypełniania tego brakującego elementu teorii, kierując zarazem studia nad ekonomią polityczną komunikacji w stronę ekonomii politycznej pracy publiczności. Aby cel ten osiagnąć, rozwinąłem pojęcie pracy publiczności, dostarczając teorii procesu pracy publiczności, a następnie podkreśliłem najbardziej fundamentalne aspekty stosunku pomiędzy praca publiczności a kapitałem, włączając podstawowy proces, poprzez który komunikacyjny kapitał wyzyskuje pracę publiczności., Aby jednak pełniej rozwinać polityczną ekonomię pracy publiczności i wykorzystać ją do analizy kapitalistycznego sposobu cyfrowej produkcji komunikacyjnej, potrzeba jeszcze wiele pracy. Wydaje się również, że duży potencjał poznawczy nieść moga ze sobą próby prześledzenia długiej historii wyzysku pracy publiczności z perspektywy komunikacji jako kapitału czy też kapitalistycznego sposobu komunikacyjnej produkcji*.

\section{Przetosyt Jakub Krzeski Redakcja: Kamil Piskała}

\footnotetext{
* Chciałbym w tym miejscu podziękować serdecznie Annie Piekarskiej - dzięki jej uwagom tłumaczenie zyskało na czytelności i klarowności. Wszystkie słabości tłumaczenia są jednak wyłącznie moją winą (przyp. tłum.).
} 


\section{Wykaz literatury:}

Andrejevic, Mark. 2002. „The Work of Being Watched: Interactive Media and the Exploitation of Self- Disclosure." Critical Studies in Media Communication 19(2): 230-248.

Andrejevic, Mark. 2007. iSpy: Surveillance and Power in the Interactive Era. Lawrence, KS: University Press of Kansas.

Andrejevic, Mark. 2011. „Surveillance and Alienation in the Online Economy.” Surveillance \& Society 8(3): 278- 287.

Benkler, Yochai. 2008. Bogactwo sieci:Jjak produkcja społecæna zmienia rynki i wolność. Tłum. Rafal Próchniak. Warszawa: Wydawnictwo Akademickie i Profesjonalne.

Caraway, Brett. 2011. „Audience Labor in the New Media Environment: A Marxian Revisiting of the Audience Commodity." Media, Culture \& Society 33(5): 693-708.

Chen, Chih-hsien. 2003. „Is the Audience Really Commodity?: An Overdetermined Marxist Perspective of the Television Economy." Paper presented at the Annual Meeting of the International Communication Association, San Diego, CA.

Cohen, Nicole S. 2008. „The Valorization of Surveillance: Towards and Political Economy of Facebook." Deomocratic Communiqué 22(1): 5-22.

Fiske, John. 1987. „Active Audiences.” W Television Culture. London: Metheun.

Fuchs, Christian. 2010. „Labor in Informational Capitalism and on the Internet.” The Information Society 26(3): 179-196.

Fuchs, Christian. 2011a. „An Alternative View of Privacy on Facebook.” Information 2(1): 140-165.

Fuchs, Christian. 2011b. „Web 2.0, Prosumption, and Surveillance.” Surveillance \& Society 8(3): 288-309.

Fuchs, Christian. 2012. „Dallas Smythe Today - The Audience Commodity, the Digital Labour Debate, Marxist Political Economy and Critical Theory: Prolegomena to a Digital Labour Theory of Value." tripleC: Cognition, Communication, Co-operation 10(2): 692-740.

Gillespie, Tarleton. 2007. Wired Shut: Copyright and the Shape of Digital Culture. Cambridge, MA: The MIT Press.

Hall, Stuart. 1987. „Kodowanie i dekodowanie.” Tłum. Wanda Lipnik i Ireneusz Siwiński. Przekasy i Opinie 1-2: 58-71.

Harvey, David. 2002. „The Art of Rent: Globalization, Monopoly and the Commodification of Culture." Socialist Register 38: 93-110, http://socialistregister.com/index.php/srv/article/view/5778/2674

Harvey, David. 2006. The Limits to Capital. London: Verso.

Harvey, David. 2010. A Companion to Marx's Capital. London: Verso.

Harvey, David. 2012. „History Versus Theory: A Commentary on Marx’s Method in Capital.” Historical Materialism 20(2): 3-38.

Hebblewhite, William Henning James. 2012. „»Means of Communication as Means of Production« Revisited.” tripleC: Cognition, Communication, Co-operation 10(2): 203-213.

Horkheimer, Max i Theodor W. Adorno. 2010. Dialektyka oświecenia. Tłum. Małgorzata Łukasiewicz. Warszawa: Wydawnictwo Krytyki Politycznej.

Jhally, Sut. 1982. „Probing the Blindspot: The Audience Commodity.” Canadian Journal of Political and Social Theory 6(1-2): 204-210.

Jhally, Sut i Bill Livant. 1986. „Watching as Working: The Valorization of Audience Consciousness." Journal of Communication 36(3): 122-142. 
Lessig, Lawrence. 2005. Wolna kultura. Tłum. zbiorowe. Warszawa: Wydawnictwo Szkolne i Pedagogiczne.

Livant, Bill. 1982. „Working at Watching: A Reply to Sut Jhally.” Canadian Journal of Political and Social Theory 6(1-2): 211-215.

Marks, Karol. 1951. Kapitat: Krytyka ekonomii politycznej. Tom 1. Warszawa: Książka i Wiedza.

Marks, Karol. 1986. Zarys krytyki ekonomii politycznej. Tłum. Zygmunt Jan Wyrozembski. Warszawa: Książka i Wiedza.

Meehan, Eileen R. 1984. „Ratings and the Institutional Approach: A Third Answer to the Commodity Question." Critical Studies in Mass Communication 1(2): 216-225.

Nixon, Brice. 2012. Dialectical Method and the Critical Political Economy of Culture. triple-C: Cognition, Communication, Co-operation 10 (2): 439-456.

Nixon, Brice. 2013. „Communication as Capital and Audience Labor Exploitation in the Digital Era." Praca doktorska, University of Colorado Boulder. ProQuest (UMI 3592351).

Peck, Janice. 2002. „The Oprah Effect: Texts, Readers, and the Dialectic of Signification.” The Communication Review 5(2): 143-178.

Peck, Janice. 2006. „Why We Shouldn’t Be Bored with the Political Economy Versus Cultural Studies Debate." Cultural Critique 64: 92-126.

Schiller, Dan. 1996. Theorizing Communication: A History. Oxford: Oxford University Press.

Shimpach, Shawn. 2005. „Working Watching: The Creative and Cultural Labor of the Media Audience." Social Semiotics 15(3): 343-360.

Smythe, Dallas W. 1977. „Communications: Blindspot of Western Marxism.” Canadian Journal of Political and Social Theory 1(3): 1-27.

Smythe, Dallas W. 1978. „Rejoinder to Graham Murdock.” Canadian Journal of Political and Social Theory 2(2): 120-127.

Terranova, Tiziana. 2000. „Free Labor: Producing Culture for the Digital Economy.” Social Text 63: 33-58.

Williams, Raymond. 1980a. „Base and Superstructure in Marxist Cultural Theory.” W Williams, Raymond, Problems in Materialism and Culture. London: Verso, s. 31-49.

Williams, Raymond. 1980b. „Means of Communication as Means of Production.” W Williams, Raymond, Problems in Materialism and Culture. London: Verso, s. 50-63.

Williams, Raymond. 1981. The Sociology of Culture. Chicago: The University of Chicago Press.

Williams, Raymond. 1989. Marksizm i literatura. Tłum. Antoni Chojnacki i Edward Kasperski. Warszawa: Państwowe Wydawnictwo Naukowe. 
Brice Nixon - jest niezależnym badaczem, zatrudnionym wcześniej w charakterze adiunkta na Wydziale Studiów Komunikacyjnych w Baruch College i Wydziale Mediów, Kultury i Komunikacji na New York University. Otrzymał tytuł doktora na University of Colorado Boulder w 2013 roku broniąc rozprawy doktorskiej pod tytułem Communication as Capital and Audience Labor Exploitation in the Digital Era.

CYTOWANIE: Nixon, Brice. 2015. W stronę ekonomii politycznej „pracy publiczności” w erze cyfrowej. „Praktyka Teoretyczna” 1(15): 124-158.

DOI: $10.14746 /$ prt.2015.1.4

\section{AUTHOR: Brice Nixon}

TITLE: Toward a political economy of 'audience labour' in the digital era

ABSTRACT: This article contributes to a political economic theory centred on the concept of "audience labour". First, the previous use of the concept of audience labour is briefly traced and the process of rethinking the concept as the basis of a political economic theory is begun. Second, a theory of the audience labour process is developed, drawing on previous theories of audience activities of cultural consumption as productive activities of signification and adapting Marx's theory of the human labour process to the audience labour process. Third, a political economy of audience labour is outlined. As a theory of the basic processes through which communicative capital can control and extract value from audience labour, it describes the exploitation of audience labour and accumulation of communicative capital through distribution relationships of rent and interest. Finally, the continuing centrality of audience labour exploitation in the digital era is discussed.

KEYWORDS: Audience Labour, Communicative Capital, Communicative Production, Signification, Cultural Consumption, Dallas Smythe, Karl Marx, Raymond Williams, David Harvey, Exploitation, Rent, Interest 